\title{
Origin of Carboniferous sandstones fringing the northern margin of the Wales-Brabant Massif: insights from detrital zircon ages
}

\author{
ANDREW MORTON ${ }^{1,2^{*}}$, COLIN WATERS ${ }^{3}$, MARK FANNING $^{4}$, IAN \\ CHISHOLM $^{5}$ and MATT BRETTLE ${ }^{6}$ \\ ${ }^{1}$ HM Research Associates, 2 Clive Road, Balsall Common, CV7 7DW, UK \\ ${ }^{2}$ CASP, University of Cambridge, 181a Huntingdon Road, Cambridge CB3 0DH, UK \\ ${ }^{3}$ British Geological Survey, Keyworth, Nottingham NG12 5GG, UK \\ ${ }^{4}$ Research School of Earth Sciences, The Australian National University, Canberra \\ ACT0200, Australia \\ ${ }^{5} 4$ Park Street, Loughborough, Leicestershire, LE11 2EG, UK \\ ${ }^{6}$ Premier Oil UK Limited, 53 Blenheim Place, Aberdeen AB25 2DZ, UK
}

*Correspondence to: Andrew Morton, HM Research Associates, 2 Clive Road, Balsall Common, CV7 7DW, UK. Email: heavyminerals@hotmail.co.uk 


\begin{abstract}
A study of detrital zircon age populations in Namurian-Westphalian (Carboniferous) sandstones in the southern Central Pennine Basin of the UK has revealed considerable complexity in their provenance history. The Pendleian-Marsdenian Morridge Formation, which is known to have been derived from the Wales-Brabant Massif to the south on the basis of palaeocurrent and petrographic information, is dominated by zircons ultimately derived from the Caledonian belt to the north. These zircons were recycled from sandstones of northern origin that had been previously deposited over the massif during Middle to Late Devonian times. The Morridge Formation also includes Late Neoproterozoic zircons of local Wales-Brabant Massif origin. The south lobe of the Yeadonian Rough Rock has been previously interpreted as having a complex provenance including sediment of northern origin interbedded with sediment ascribed to a WalesBrabant Massif source. However, the zircon spectrum lacks a Late Neoproterozoic component that would have been diagnostic of input from the Wales-Brabant Massif, and the provenance history of the Rough Rock south lobe therefore remains enigmatic. The Langsettian Ludgbridge Conglomerate is dominated by Late Neoproterozoic zircons of Wales-Brabant Massif origin, but even in this evidently proximal deposit, the provenance is complex since the main zircon group ( $c a .640 \mathrm{Ma}$ ) cannot be matched with known local Neoproterozoic basement sources. The data either indicate the presence of hithertounknown magmatic rocks of this age adjacent to the South Staffordshire coalfield, or indicate that the zircons were recycled from sediment with a more distal origin. Finally, the Duckmantian Top Hard Rock contains zircons that can be reconciled with a source in the Irish Caledonides, consistent with the palaeocurrent evidence, supplemented by zircons derived from the Wales-Brabant Massif, possibly including the Monian Composite Terrane of Anglesey. The study reinforces the important message that failure to recognize the presence of recycled zircon could lead to erroneous reconstructions of sediment provenance and transport history.
\end{abstract}

KEY WORDS Carboniferous; Wales-Brabant Massif; sandstones; detrital zircon ages; provenance

Supplementary U-Pb zircon data accompany the main document 


\section{INTRODUCTION}

The Central Pennine Basin, which is defined as the area lying between the Craven Fault system in the north and the Wales-Brabant Massif (WBM) in the south (Fig. 1), was the locus of clastic deposition through most of Carboniferous time (Waters and Davies, 2006). By late Visean times, basinal mudstone deposition (Craven Group) was widely established, and this continued into the early Namurian. Major river systems then advanced across the basin, leading to diachronous deposition of coarser-grained fluviodeltaic deposits that comprise the Millstone Grit Group (Gilligan, 1920; Leeder, 1988; Waters et al., 2009). These entered the northern part of the basin during the late Pendleian, subsequently became widespread during the Kinderscoutian, and by Marsdenian times had reached the northern margin of the WBM (Collinson, 1988, fig. 9.6; Waters and Davies, 2006). The northern location of this sediment source is shown by a wide range of provenance indicators including palaeocurrents, petrography, heavy minerals, garnet geochemistry, zircon and monazite ages, whole-rock Sm-Nd model ages, white mica ages and Pb-isotopes in feldspar (Gilligan, 1920; Cliff et al., 1991; Bristow, 1993; Glover et al., 1996; Evans et al., 2001; Hallsworth et al., 2000; Stuart et al., 2001; Tyrrell et al., 2006; Hallsworth and Chisholm, 2008). Major supply of sediment from the north continued into early Westphalian times, but was replaced gradually by inflows of fluviodeltaic sediment from the west, and then from regions affected by the Variscan orogeny, to the south (Chisholm and Hallsworth, 2005).

In addition to the dominant northerly-derived coarse clastic sediment, sandstones were also shed northwards from the WBM into the southern part of the Central Pennine Basin by small fluviodeltaic systems (Trewin and Holdsworth, 1973; Aitkenhead, 1977;

Chisholm et al., 1988). Those of Namurian age are represented by the Morridge Formation, part of the Millstone Grit Group (Waters et al., 2009), the extent of which is shown in Figure 2. Deposition of these southerly-derived sandstones commenced in the Pendleian and extended into the Marsdenian (Fig. 3), after which the deposits were interbedded and mixed with those of the larger northerly-sourced delta systems such as that of the Roaches Grit (Chisholm et al., 1988) and the Rough Rock (Bristow, 1988; Chisholm and Hallsworth, 2005). The WBM may also have contributed some sediment during post-Namurian (Langsettian-Duckmantian) times (Chisholm and Hallsworth, 2005). Petrographically, the sandstones sourced from the WBM are mainly protoquartzites (Trewin and Holdsworth, 1973), in marked contrast to those of northerly 
origin, which are considerably more feldspathic (Gilligan, 1920; Bristow, 1988; Tyrrell et al., 2006).

The purpose of this paper is to provide insights into the provenance of sandstones shed from the WBM, on the basis of $\mathrm{U}-\mathrm{Pb}$ isotopic data acquired from detrital zircons using the sensitive high-resolution ion microprobe (SHRIMP). In particular, we investigate whether the sands were derived from the rocks forming the basement of the WBM, or whether they have exotic zircons indicating that they were recycled from sandstones previously deposited over the structure. The study also assesses the extent of regional and stratigraphic variations in provenance. In order to achieve this, we concentrated on Pendleian-Marsdenian sandstones in two areas in Staffordshire and Derbyshire (Figs. 2 and 3), but also included younger sandstones interpreted as having WBM sourcing (Fig. 4), namely the Yeadonian Rough Rock south lobe (Bristow, 1988; Chisholm and Hallsworth, 2005) and the Duckmantian Top Hard Rock (Chisholm and Hallsworth, 2005). We also included a very coarse-grained Langsettian sample from the South Staffordshire Coalfield, located in an embayment on the northern margin of the WBM (Figs. 2 and 4), for comparative purposes. Finally, zircons from two samples of Old Red Sandstone (ORS) cored in a borehole (Merevale 2) located on the WBM (Figs 2 and 4) were analysed to determine if ORS recycling could have been involved in sourcing the Carboniferous sediments.

\section{STRATIGRAPHIC AND SEDIMENTOLOGICAL CONTEXT}

\subsection{Morridge Formation}

The Morridge Formation, named by Waters et al. (2009) after a gritstone edge (scarp) at Morridge [SK 03 60], 2 km east of Leek, incorporates Namurian clastic sediment derived from the south. The formation is present only in the southern part of the Central Pennine Basin, along the northern margin of the WBM, where it extends across the Goyt Trough of the North Staffordshire Basin and the Widmerpool Half-Graben of the East Midlands (Fig. 2). The formation is up to $600 \mathrm{~m}$ thick, thinning northward as it passes, by interdigitation, into basinal mudstones of the Bowland Shale Formation (Craven Group). It includes a number of distinct sandstone units (Aitkenhead et al., 1985; Chisholm et al., 1988). Those sampled for the present study are the Minn, Hurdlow, Cheddleton, Kniveden and Brockholes sandstones (Fig. 3). 
The formation comprises interbedded dark grey shaly mudstones and pale grey protoquartzitic siltstones and sandstones, with minor ironstone, dolostone and limestone. Turbidites dominate the entire thickness of the formation in the northern parts of the North Staffordshire Basin (Trewin and Holdsworth, 1973; Aitkenhead et al., 1985) and the Widmerpool Half-Graben at Duffield (Aitkenhead, 1977). In both these areas, palaeocurrent directions determined from cross-laminations and sole structures indicate derivation from the south (Aitkenhead, 1977; Aitkenhead et al., 1985). Further south, closer to the WBM, shallow-water fluviodeltaic facies are locally developed (Chisholm et al., 1988).

Boreholes providing samples used in this study are the Ipstones Edge Borehole (SK05SW8) [SK 0258 5109], described by Chisholm et al. (1988, fig. 15), and the Duffield Borehole (SK34SW5) [SK 3428 4217], described by Aitkenhead (1977). The Cheddleton and Hurdlow sandstones were sampled from the Ipstones Edge Borehole (Fig. 2), and the nearby Combes Valley provided samples of the Kniveden and Brockholes sandstones. Although the sandstones in the Duffield Borehole are not named, there are excellent biostratigraphical controls provided by ammonoids, allowing correlation with the North Staffordshire sand bodies. Samples from Duffield are timeequivalents of the Minn and Cheddleton sandstones; for the sake of brevity, those names are used in Figure 3 and the following text.

\subsubsection{Minn Sandstones}

The oldest quartzitic sandstones of Namurian age in the North Staffordshire Basin are the turbiditic Minn Sandstones, which range from Pendleian to Arnsbergian in age, E1b to E2a ammonoid subzones (Aitkenhead et al., 1985; Chisholm et al., 1988). The sandstones are interbedded with siltstone and mudstone, occurring in packages separated by mudstone and calcareous siltstone (Trewin and Holdsworth, 1973, fig. 1; Aitkenhead et al., 1985, fig. 26). Palaeocurrents flowed consistently from the south, and proximal turbidites west of Leek pass northwards and eastwards into distal turbidites (Trewin and Holdsworth, 1973, fig. 5). Age-equivalent sandstones are present in the Duffield Borehole, and were sampled at $162.1 \mathrm{~m}$ depth (EH17899) and $254.8 \mathrm{~m}$ (EH17909) (Fig. 3). Sole structures indicate transport from the south (Aitkenhead, 1977). Although there is no lateral east-west continuity of the Minn Sandstones in the area between the North Staffordshire Basin and the Duffield Borehole, it is likely that they represent coeval turbidite fans sourced from the WBM. 


\subsubsection{Hurdlow Sandstones}

The Hurdlow Sandstones are turbiditic protoquartzites deposited in the North Staffordshire Basin during late Arnsbergian (E2c) times (Aitkenhead et al., 1985; Chisholm et al., 1988). Sole marks and ripple cross-lamination indicate palaeocurrent flow towards the north (Chisholm et al., 1988). The sandstones were sampled in the Ipstones Edge Borehole (sample EH11803) at 178.45 m depth (Fig. 3).

\subsubsection{Cheddleton Sandstones}

The Cheddleton Sandstones are protoquartzites of Chokierian and Alportian age in the south part of the North Staffordshire Basin. The sandstones, which are fine- to coarsegrained and locally pebbly, are interpreted as fluviodeltaic in origin (Chisholm et al., 1988). Further to the north, turbiditic sandstones of Chokierian age are termed the Lum Edge Sandstones (Aitkenhead et al., 1985). The Cheddleton Sandstones in the Ipstones Edge Borehole, which comprise well-bedded fine- and medium-grained sandstones with coarse bands, were sampled at 70.75 m depth (sample EH11800) (Fig. 3). Ripple crosslamination indicates palaeocurrent flow towards the north (Chisholm et al., 1988). Sandstones of equivalent age are also present in the Duffield Borehole (sample EH17896) at 5.5-5.8 m depth, comprising sandstone with interbedded laminated siltstone and mudstone with graded bedding and sole structures. This suggests that age-equivalents of the Cheddleton Sandstones are developed as turbidites in the Widmerpool Half-Graben.

\subsubsection{Kniveden Sandstones}

The Kniveden Sandstones of Aitkenhead et al. (1985) are protoquartzites deposited in the North Staffordshire Basin during late Kinderscoutian (R1c) times. In the Combes Valley, they comprise fine- to coarse-grained, poorly bedded, cross-bedded and flat bedded sandstone with scattered pebbles, mudstone and ironstone intraclasts, and fine-grained, ripple-laminated, thin-bedded sandstone, interbedded with purple-grey siltstone (Chisholm et al., 1988, p.42), interpreted as shallow-water fluvio-deltaic deposits. A finegrained sandstone was sampled at Spiritholes Wood, Combes Valley [SK 0055 5228] (Sample WQ189; Fig. 3). The unit passes northwards towards Leek where the sandstones are turbiditic (Aitkenhead et al., 1985).

East of the Ipstones Edge Borehole, the absence of key marine bands makes differentiation of the Cheddleton and Kniveden units impossible, and the sandstones are combined as the Ipstones Edge Sandstones, unsampled in this study. The increase in the 
proportion of sandstone was suggested by Chisholm et al. (1988) as indicating that the merged unit is closer to the source of the clastic supply.

\subsubsection{Brockholes Sandstones}

The youngest quartzitic beds in the North Staffordshire Basin, the Brockholes Sandstones, are of mid-Marsdenian (R2b) age. They interdigitate with the basal feldspathic sandstone (the Roaches Grit) of the Marsden Formation (Chisholm et al., 1988). The sandstones are shallow-water in origin, dying out east of the Ipstones Edge Borehole. A medium- to very coarse-grained sandstone in this unit was sampled at Low Wood [SK 0055 5185] (Sample WQ190) (Figs. 2 and 3).

\subsection{Millstone Grit Group (excluding Morridge Formation)}

Feldspathic sandstones from a northern provenance did not reach the south part of the Pennine Basin until mid-Namurian times. The first influx is represented by the Longnor Sandstones, which entered the northern part of the North Staffordshire Basin in late Kinderscoutian (R1c) times. Later incursions extended across most of the North Staffordshire Basin and the Widmerpool Half-Graben area. These comprise the Ashover and Roaches grits in mid-Marsdenian (R2b) times, followed by the Chatsworth Grit (in R2c) and the Rough Rock (in G1).

The Rough Rock is of Yeadonian (end-Namurian) age. Its nature and distribution were described by Bristow $(1988,1993)$. The main sand body is a sheet-like, pebbly, mainly trough cross-bedded, very coarse-grained to granular sandstone, interpreted as the deposits of a braidplain fluvial system. The dominant palaeocurrent direction is towards the southwest. This main lobe is extensively developed across Yorkshire, but is locally absent south of Sheffield. A separate southern lobe with a higher quartz:feldspar ratio and palaeocurrents towards the west extends along the Widmerpool Half-Graben. The distinction between the main and south lobes was confirmed by heavy mineral evidence (Hallsworth and Chisholm, 2008, p. 210), but the proposed westward extent of the south lobe into the North Staffordshire Basin is unlikely, because the sandstones there contain unmodified northern heavy mineral suites.

Zircon ages associated with the main lobe of the Rough Rock have been described by Cliff et al. (1991) and Hallsworth et al. (2000). To test for possible contributions from the WBM to the south lobe of the Rough Rock, sample ZA4564 was collected from Castle 
Farm, Coxbench [SK 3740 4320] (Figs. 2 and 4). Palaeocurrents here flowed consistently from the east (Bristow, 1988, fig. 11.8; Hallsworth and Chisholm 2008, fig. 13), but heavy mineral assemblage compositions indicate the presence of both northern sediment and sediment of a different origin, ascribed to the WBM (Hallsworth and Chisholm 2008, figs, 11 and 13).

\subsection{Pennine Coal Measures Group}

The Pennine Coal Measures Group comprises cyclic alternations of sandstone, siltstone and mudstone, with coal seams and palaeosol horizons. Mudstones commonly contain non-marine faunas or, less commonly, marine faunas ('marine bands'). There is a general upwards decrease in the number and thickness of marine bands, and a contrasting increase in the importance of coals and seatearths from the Millstone Grit Group into the Coal Measures.

Provenance of sandstones varied through the Coal Measures succession, and also geographically, as shown by petrographic evidence (Chisholm, 1990), heavy mineral and garnet geochemical studies, (Chisholm et al., 1996; Hallsworth et al., 2000; Hallsworth and Chisholm, 2000; Chisholm and Hallsworth, 2005; Hallsworth and Chisholm, 2008), radiometric dating of detrital minerals (Glover et al., 1996; Leng et al., 1999; Hallsworth et al., 2000; Evans et al., 2001), reworked palynomorphs (Chisholm et al., 1996), palaeocurrent directions (Besly, 1988; Chisholm, 1990; Hallsworth and Chisholm, 2000; Chisholm and Hallsworth, 2005; Hallsworth and Chisholm, 2008), and sandstone channel trends (Rippon, 1996). The earliest sandstones were derived from the north, continuing the pattern of the underlying Millstone Grit. Sandstones derived from the west appeared above the level of the Upper Band Coal, gradually increased in importance, and became dominant above the Vanderbeckei Marine Band. Sandstones derived from distant southern sources replaced those from the western source at about the level of the Aegiranum Marine Band. This pattern relates mainly to the central part of the Pennine Basin; in its southernmost part (the present study area), sediment derived from proximal southern sources was added to these various components at times throughout the Westphalian (Chisholm and Hallsworth, 2005; Hallsworth and Chisholm, 2008).

Two samples were analysed for the present study. The first is from the South Staffordshire Coalfield (Fig. 4), where the base of the Coal Measures is an unconformity: the earliest part of the succession, including the Subcrenatum Marine Band, is absent. 
The lowest bed, of Langsettian age, is the Ludgbridge Conglomerate, which comprises conglomerates and coarse-grained sandstones (Waters et al., 2013). The sample (HM17578) was taken from a sandstone within the conglomerate at Doulton's Clay Pit [SO 933 870], south of Dudley, West Midlands (Fig. 2). The coarse-grained pebbly nature of this deposit, and its location on the WBM (Fig. 2), indicate a likely local provenance in the WBM.

The second sample is from the Top Hard Rock, of Duckmantian age, in the Derbyshire Coalfield (Figs. 2 and 4; Aitkenhead et al. 2002, fig. 23). The sample (ZA4563) is a medium-grained sandstone, $0.5 \mathrm{~m}$ above the Top Hard Coal, from Miller's Pond, Hardwick [SK 4540 6437]. This sandstone was selected since heavy mineral and garnet assemblages at this locality indicated deposition from a western transport system, but with a contribution from a southern source, inferred to be the WBM (Chisholm and Hallsworth, 2005, p. 224).

\subsection{Late Devonian}

Late Devonian Upper Old Red Sandstone (ORS) strata have been sampled in the Merevale 2 Borehole, in order to investigate the possible role of ORS as a source of sediment shed from the WBM into the Pennine Basin. The Late Devonian succession of the Merevale area has a mapped extent of $2.5 \mathrm{~km}$ along the western edge of the Nuneaton Inlier, terminating to the northwest against the Arley Fault (Bridge et al., 1998). Referred to as the Oldbury Farm Sandstone Formation by Bridge et al. (1998), it represents part of the Upper Old Red Sandstone Group. The type section is the Merevale 2 Borehole (SP39NW6) [SP 3001 9509], described in detail by Taylor and Rushton (1971) and Bridge et al. (1998), with approximately $152 \mathrm{~m}$ true thickness present in the borehole (from 53.9 m to 213.7 m depth; Fig. 4).

The formation comprises greyish green conglomerates, sandstones, siltstones and reddish brown and green silty and sandy mudstones. Typically occurring in upward-fining cycles, the succession was deposited in alluvial fan and fluviatile systems, with subordinate marginal marine environments.

The base of the formation is marked by a conglomerate with subordinate sandstone layers, and rests with a sharp base on the underlying Merevale Shale Formation (Stockingford Shale Group), of Cambrian age. Greyish green massive siltstone with 
mudstone fragments and large roots in the top $15 \mathrm{~cm}$ of the Oldbury Farm Sandstone Formation is sharply overlain by pale grey sandstone with carbonised woody fragments assigned to the Millstone Grit.

Four informal members are recognised in the Merevale 2 Borehole by Bridge et al. (1998). The lowermost member (Member 1), between $213.7 \mathrm{~m}$ and $178.9 \mathrm{~m}$, shows a progressive upward-fining succession. The beds form repetitive cycles, each commencing with a conglomerate, fining up into sandstone and finally mudstone (Bridge et al., 1998). The sandstone component of the member is interpreted as being deposited in point-bars within alluvial channels, with the mudstones accumulating as overbank floodplain deposits (Bridge et al., 1998). Sample EH14126 is from $181.3 \mathrm{~m}$ depth, a greenish grey, poorly-sorted, very coarse-grained, cross-bedded sandstone from the upper part of this member (Fig. 4).

Member 2, from $178.9 \mathrm{~m}$ to $144 \mathrm{~m}$, which was not analysed in this study, is distinguished by the presence of lingulid and phyllocarid fossils (and a single occurrence of crinoid columnals), proving deposition in a marginal marine environment (Bridge et al., 1998). Conglomerates between $0.05 \mathrm{~m}$ and $0.2 \mathrm{~m}$ thick form the base to many upward-fining sedimentary cycles; they have a silty or coarse-grained sand matrix containing shell and fish debris, and resemble lag deposits. Pebbly sandstones that gradationally overlie the conglomerates contain siltstone, mudstone, quartz and igneous rock fragments, and concentrations of fish and shell debris. Other sandstones are green to grey and argillaceous or calcareous, with drifted plant stems and intensely burrowed mudstone or siltstone laminae.

Member 3, from $144 \mathrm{~m}$ to $115 \mathrm{~m}$, was also not analysed in this study. It is more thickly bedded than the underlying member and is devoid of marine fossils (Bridge et al., 1998). The member is dominated by cyclic repetitions, up to several metres thick, commencing with erosively based conglomerate and fining upwards to thin cappings of highly burrowed mudstone or siltstone. Well-bedded intervals comprise alternations between very coarse-grained and fine-grained layers, and many beds show normal grading to very coarse-grained or conglomeratic sandstone at the base. This member probably represents a reversion to deposition in meandering river systems (Bridge et al., 1998).

Member 4, from $115 \mathrm{~m}$ to $53 \mathrm{~m}$, is distinguished by containing beds of nodular carbonate and limestone-clast conglomerate (Bridge et al., 1998). The sequence is dominated in its 
lower part by thick upward-fining sedimentary cycles, but higher up the coarse-grained beds become less prominent and greyish green to reddish brown mudstone or greyish green micaceous siltstone beds are correspondingly thicker. The sandstones are greyish green to pale grey and micaceous with a hard calcareous cement. They are mainly finegrained, but are medium- to coarse-grained towards bed bases and commonly contain sporadic limestone pebbles and mudstone flakes. Sample EH14116 was collected from a pale grey-green, fine-grained massive sandstone at $100.2 \mathrm{~m}$ depth (Fig. 4). The increased carbonate content is typical of calcrete formation in tropical and sub-tropical soils, suggestive of intermittent semi-arid conditions.

Many of the larger clasts in the Oldbury Farm Sandstone Formation indicate derivation from an acid volcanic terrain, but petrographically they do not resemble the nearby Precambrian Caldecote Volcanic Formation. Taylor and Rushton (1971) suggested they resemble clasts within the ORS of the Church Stretton area, though derivation from a postulated late Ordovician volcanic system on the eastern margin of the Midlands Microcraton (Pharaoh et al., 1993) was considered to be another possibility.

\section{ANALYTICAL METHODS}

Zircon grains were separated from the samples using standard crushing, washing, heavy liquid (Sp. Gr. 2.96 and 3.3), and paramagnetic procedures. The zircon-rich heavy mineral concentrate was poured onto double-sided adhesive tape, mounted in epoxy together with chips of the reference zircons (FC1, Temora and SL13), sectioned approximately in half, and polished. Reflected light photomicrographs, transmitted light photomicrographs and cathodoluminescence (CL) scanning electron microscope (SEM) images were prepared for all zircon grains. The CL images were used to decipher the internal structures of the sectioned grains and to ensure that the $20 \mu \mathrm{m}$ SHRIMP spot was wholly within a single age component within the sectioned grains. Where possible, the SHRIMP spot was placed in the youngest zone of grains with evidence of multistage growth.

The U-Th-Pb analyses were made using SHRIMP RG at the Research School of Earth Sciences, The Australian National University, Canberra, Australia. The zircons on the mount were analyzed sequentially and randomly until a total of 70 grains was reached. Each analysis consisted of 5 scans through the mass range, with a reference zircon analyzed for every five unknown zircon analyses, following the SHRIMP analytical 
method recommended by Williams (1998, and references therein). The data have been reduced using the SQUID Excel Macro of Ludwig (2001).

The U/Pb ratios have been normalized relative either to a value of 0.0668 for the Temora reference zircon, equivalent to an age of $417 \mathrm{Ma}$ (Black et al., 2003), or to a value of 0.1589 for the FC1 reference zircon, equivalent to an age of 1099 Ma (Paces and Miller, 1993). Uncertainties given for individual analyses (ratios and ages) are at the one sigma level. Correction for common $\mathrm{Pb}$ was made using the measured ${ }^{204} \mathrm{~Pb} /{ }^{206} \mathrm{~Pb}$ ratio in the normal manner, except for grains younger than $\sim 800 \mathrm{Ma}$ and for grains with low $U$ and, therefore, low radiogenic $\mathrm{Pb}$, in which case the ${ }^{207} \mathrm{~Pb}$ correction method was used (Williams, 1998). When the ${ }^{207} \mathrm{~Pb}$ correction is applied, it is not possible to determine radiogenic ${ }^{207} \mathrm{~Pb} /{ }^{206} \mathrm{~Pb}$ ratios or ages. For areas younger than $\sim 800 \mathrm{Ma}$, and for areas that are low in $\mathrm{U}$ and therefore low in radiogenic $\mathrm{Pb}$, the radiogenic ${ }^{206} \mathrm{~Pb} /{ }^{238} \mathrm{U}$ age has been used for the probability density plots. The ${ }^{207} \mathrm{~Pb} /{ }^{206} \mathrm{~Pb}$ age is used for grains older than $800 \mathrm{Ma}$, or for younger grains enriched in $\mathrm{U}$. The full dataset is available in a Supplementary File.

\section{RESULTS}

$\mathrm{U}-\mathrm{Pb}$ isotopic compositions and ages of zircons in the twelve analysed samples are shown on Tera-Wasserburg concordia diagrams (Fig. 5) and probability-density diagrams (Figs. 6a and b). The great majority have compositions that are $<10 \%$ discordant. A small number of grains have relatively high common Pb, notably in ZA4563 (Top Hard Rock, Duckmantian) and in ZA4564 (Rough Rock south lobe, Yeadonian): such analyses are excluded from the probability-density diagrams.

\subsection{Sample EH14126: Upper Old Red Sandstone, 181.3 m, Merevale 2 Borehole}

The zircon spectrum in this sample is dominated by late Neoproterozoic and early Palaeozoic ages. The main group is between $c a$. 410-490 Ma, with two subordinate groups at ca. 550-560 Ma and ca. 600-630 Ma, and other minor representation in the 500700 Ma range. Older Precambrian ages are wide-ranging, from ca. 1000 Ma to ca. 3200 $\mathrm{Ma}$, but are scattered throughout this range without any obvious groupings.

\subsection{Sample EH14116: Upper Old Red Sandstone, 100.2 m, Merevale 2 Borehole}


The zircon spectrum in this sample is dominated by Proterozoic grains, ranging from $c a$. 920 Ma to ca. 1820 Ma. There is representation across this entire range, but there are particular groupings at $c a$. 920-1140 Ma and 1720-1820 Ma. In addition, there is a single Archaean grain (ca. $2670 \mathrm{Ma}$ ), three Neoproterozoic grains (546 Ma, $580 \mathrm{Ma}, 710 \mathrm{Ma}$ ) and three Silurian grains (426-434 Ma).

\subsection{Sample EH17909: Minn Sandstones, Pendleian, 254.8 m, Duffield Borehole}

The lower of the two Minn Sandstones zircon populations from the Duffield Borehole is dominated by late Neoproterozoic and early Palaeozoic grains. The main grouping is between $410 \mathrm{Ma}$ and $480 \mathrm{Ma}$, and is apparently bimodal. There are also two younger zircons (mid-Devonian) dated at $387 \mathrm{Ma}$ and $395 \mathrm{Ma}$ and three older (Cambrian) grains (498-516 Ma). The majority of the Neoproterozoic zircons fall between ca. $580 \mathrm{Ma}$ and ca. 630 Ma. The older Proterozoic is an important subsidiary component, and displays a wide range of ages, virtually all between $c a .1000$ Ma and ca. 2090 Ma.

\subsection{Sample EH17899: Minn Sandstones, Arnsbergian, 162.1 m, Duffield Borehole}

The upper of the two Minn Sandstones zircon populations from the Duffield Borehole is also dominated by the late Neoproterozoic and early Palaeozoic. The main grouping is between $c a$. 400-470 Ma, and appears to be bimodal with a larger younger component (peaking at $c a .430 \mathrm{Ma}$ ) and a smaller older group (peaking at $c a .460 \mathrm{Ma}$ ). There is a smaller Neoproterozoic-Cambrian group, peaking in the ca. 530-540 Ma range. The older Proterozoic forms a subsidiary component, and displays a wide range of ages, virtually all between ca. $990 \mathrm{Ma}$ and ca. $1860 \mathrm{Ma}$.

\subsection{Sample EH17896: Cheddleton Sandstones, Chokierian, 5-8 m, Duffield Borehole}

The Cheddleton Sandstones sample in the Duffield Borehole has a similar zircon spectrum to those in the underlying Minn Sandstones. The majority of zircons are late Neoproterozoic to early Palaeozoic in age, with the main group being ca. 400-480 Ma. This group appears polymodal, with the largest peak at $c a$. 420 Ma. The Neoproterozoic is represented by zircons between $c a$. $540 \mathrm{Ma}$ and $c a$. $610 \mathrm{Ma}$. The older Proterozoic is an important subsidiary component, and displays a wide range of ages, mostly falling between ca. $950 \mathrm{Ma}$ and ca. $2100 \mathrm{Ma}$. The Archaean is more conspicuous in this sample than in the Minn Sandstones, with four zircons dated between 2610 Ma and 2855 Ma. 


\subsection{Sample EH11803: Hurdlow Sandstones, Arnsbergian, 178.45 m, Ipstones Edge Borehole}

In the Ipstones Edge Borehole, the Hurdlow Sandstones sample has a zircon population that is dominated by the Mesoproterozoic to Palaeoproterozoic, with relatively minor representation of the Neoproterozoic and early Palaeozoic. The spectrum is characterized by a wide-ranging group of mid-Proterozoic zircons ranging from ca. $920 \mathrm{Ma}$ to $c a .1770$ Ma, with especially prominent peaks in the ca. 1020-1080 Ma and ca. 1640-1680 Ma ranges. There is also minor representation of the Archaean (two grains at $2711 \mathrm{Ma}$ and $2724 \mathrm{Ma}$ ). The majority of the Palaeozoic zircons are spread relatively evenly across the 400-490 Ma range, together with three zircons that span the Cambrian-Precambrian boundary (526 Ma, $531 \mathrm{Ma}, 549 \mathrm{Ma}$ ). The Neoproterozoic is represented by just three grains (628 Ma, $675 \mathrm{Ma}$ and $754 \mathrm{Ma}$ ).

\subsection{Sample EH11800: Cheddleton Sandstones, Alportian, 70.75 m, Ipstones Edge Borehole}

The zircon spectrum in the Cheddleton Sandstones sample from the Ipstones Edge Borehole is similar in many respects to that from the underlying Hurdlow Sandstones. The spectrum is characterized by a wide-ranging group of mid-Proterozoic zircons ranging from ca. $910 \mathrm{Ma}$ to $c a .1820 \mathrm{Ma}$, with especially prominent peaks in the $c a$. 1000-1080 Ma and ca. 1540-1680 Ma ranges. The majority of the Palaeozoic zircons occur in the ca. 410-480 Ma range. These have an apparently bimodal pattern, with a main peak at $c a .460 \mathrm{Ma}$ and a subsidiary peak at $c a .415 \mathrm{Ma}$. The Neoproterozoic is represented by just four grains (565 Ma, $618 \mathrm{Ma}, 647 \mathrm{Ma}, 675 \mathrm{Ma}$ ).

\subsection{Sample WQ189: Kniveden Sandstones, Kinderscoutian, Combes Valley}

This sample is comparable to the Cheddleton and Hurdlow sandstones in the nearby Ipstones Edge Borehole. The spectrum is characterized by a wide-ranging group of midProterozoic zircons ranging from ca. $920 \mathrm{Ma}$ to $c a$. $1830 \mathrm{Ma}$, with the main peak at $c a$. 1000-1120 Ma and subsidiary peaks at ca. $940 \mathrm{Ma}, 1510 \mathrm{Ma}$ and $1770 \mathrm{Ma}$. The majority of the Palaeozoic zircons occur in the 410-480 Ma range and have an apparently bimodal pattern, with a main peak at $c a$. $425 \mathrm{Ma}$ and a subsidiary peak at $c a$. 450-470 Ma. The 
Neoproterozoic part of the spectrum has a main group between $c a$. $550 \mathrm{Ma}$ and $c a .610$ Ma, with scattered representation back to $c a$. 710 Ma.

\subsection{Sample WQ190: Brockholes Sandstones, Marsdenian, Combes Valley}

The Brockholes Sandstones zircon population is also comparable to older sandstones in the Combes Valley-Ipstones Edge area. The majority of the zircons fall in a wide range from ca. $960 \mathrm{Ma}$ to $c a$. $2030 \mathrm{Ma}$, with the main grouping between ca. $960 \mathrm{Ma}$ and $c a$. $1240 \mathrm{Ma}$, a subsidiary group at ca. 1600-1740 Ma, and scattered representation elsewhere in the overall range. There is a small group of Archaean zircons (2727 Ma, $2729 \mathrm{Ma}$, $2738 \mathrm{Ma}$ ). The majority of the Palaeozoic zircons occur in the ca. 410-490 Ma range and have an apparently bimodal pattern, with a main peak at $c a .440$ Ma and a subsidiary peak at $c a .475 \mathrm{Ma}$. The Neoproterozoic part of the spectrum is also bimodal, with a younger group at ca. 530-580 Ma and an older group at ca. 600-640 Ma.

\subsection{Sample ZA4564: Rough Rock south lobe, Yeadonian, Coxbench}

The zircon spectrum in the Rough Rock south lobe sample is dominated by grains that fall in the $c a$. 400-470 Ma range. This group appears to be unimodal, peaking at $c a .435$ Ma, but is skewed towards younger ages. The sample lacks any representation in the late Neoproterozoic-Cambrian age range. There are also Proterozoic and Archaean elements. The Proterozoic zircon ages are spread across a wide range (ca. 940-2040 Ma) without any clear grouping. The Archaean component comprises seven zircons between ca. 2630 Ma and ca. 2790 Ma.

\subsection{Sample HM17578: Ludgbridge Conglomerate, Langsettian, Doulton's Clay Pit}

The Ludgbridge Conglomerate is dominated by zircons with late Neoproterozoic to Cambrian (ca. 510-700 Ma) ages. Within this range, there is one major peak at ca. 640 Ma and a subsidiary peak at $c a .530 \mathrm{Ma}$. There is very little representation of the younger Palaeozoic, with just two grains (425 Ma, $470 \mathrm{Ma}$ ). The mid-Proterozoic is also relatively poorly represented, with scattered peaks in the ca. 1030-2070 Ma range, the largest group being at $c a .1510$ Ma.

\subsection{Sample ZA4563: Top Hard Rock, Duckmantian, Hardwick}


The Top Hard Rock spectrum is characterized by two main groupings, one in the early Palaeozoic and one in the late Neoproterozoic to Cambrian. The early Palaeozoic group is itself bimodal, with a smaller group in the ca. 460-490 Ma range and a larger one in the ca. 370-440 Ma range. The spectrum is distinctive in having a relatively large proportion of zircons younger than $400 \mathrm{Ma}$, with the youngest reliably-dated grain at $369 \mathrm{Ma}$ (Fammenian). The Neoproterozoic to Cambrian group is polymodal, but the main peak is between $c a$. $610 \mathrm{Ma}$ and $c a$. $620 \mathrm{Ma}$. The older Precambrian is mostly represented by two broad groups, one comprising five zircons between ca. $970 \mathrm{Ma}$ and ca. $1200 \mathrm{Ma}$ and the second comprising twelve zircons between ca. 1740 Ma and ca. 2210 Ma. In addition, there are two older zircons dated as 2490 Ma and 2909 Ma.

\section{DISCUSSION}

\subsection{Morridge Formation (Pendleian-Marsdenian)}

As discussed above, the sandstones of the Morridge Formation are known, on the basis of palaeocurrent directions and facies distributions, to be derived from the WBM to the south. Furthermore, their quartzitic petrography indicates that this source area had a different composition to that which supplied the Namurian northerly-derived feldspathic sandstones (Trewin and Holdsworth, 1973). The zircon age data described above throw more light on the nature of these source materials.

There is comparatively little stratigraphic change in zircon age characteristics through the succession at either of the two studied locations (Duffield in the east and Ipstones EdgeCombes Valley in the west: Figs. 6a and b). However, the zircon data show that there are distinct differences in the nature of the source material between east and west (Fig. 7). In the east (Duffield Borehole), the zircon spectrum is dominated by Late Neoproterozoic and Palaeozoic zircons, which form $c a$. $53 \%$ of the $<10 \%$ discordant population. In the west (Ipstones Edge Borehole and Combes Valley), by contrast, late Neoproterozoic and Palaeozoic zircons form $c a .27 \%$ of the $<10 \%$ discordant population. The overall age distribution of the mid-Proterozoic zircons is the same in the two areas (Fig. 7), and the same two main peaks (ca. 1000-1100 Ma and ca. 1600-1700 Ma) are in evidence. However, there appears to be a difference in the relative importance of these two peaks, with the 1000-1100 Ma group being more abundant than the 1600-1700 Ma group in the Ipstones Edge/Combes Valley area. By contrast, these two groups are approximately equally represented in the Duffield Borehole. The Ipstones Edge and Combes Valley area 
also has a small but distinct Archaean component that is barely in evidence at Duffield. There is comparatively little difference in the Late Neoproterozoic to Palaeozoic part of the spectrum, both areas having most zircons in the ca. 400-490 Ma range with an additional broad group from ca. 500-700 Ma (Fig. 7).

The zircon data therefore suggest that at least two separate transport systems drained the WBM to feed the Morridge Formation sandstones at the southern end of the Central Pennine Basin, one to the Derbyshire area (sampled in the Duffield Borehole) and one to the Staffordshire area (sampled in the Ipstones Edge Borehole and Combes Valley). These transport systems evidently sampled sources with the same broad range of zircon ages, but lateral heterogeneities within the hinterland gave rise to the observed differences between the two regions.

However, despite the palaeocurrent and palaeogeographic evidence for derivation from the south, it is not possible to match the zircon data with known basement sources on the WBM. The WBM (Fig. 1) is part of eastern Avalonia, and consists of the Midlands Microcraton, flanked on the west by the Welsh Basin and on the east by the Eastern England Caledonides (Verniers et al., 2002). The Midlands Microcraton is divided into an eastern (Charnwood) terrane and a western (Wrekin) terrane (Pharaoh and Carney, 2000), both of which comprise Late Neoproterozoic basement rocks. The basement rocks of the Midlands Microcraton are overlain by predominantly mudstone-dominated clastic successions of Cambrian to Early Devonian age (Verniers et al., 2002). These are in turn overlain by Late Devonian ORS clastics (as in the Merevale 2 Borehole), which are separated from the Early Devonian succession by an unconformity related to the Acadian phase of the Caledonian Orogeny (Verniers et al., 2002). The Welsh Basin, which is part of the Cymru Terrane (Pharaoh and Carney, 2000), contains a Cambrian-Early Devonian sedimentary succession with exposures of Neoproterozoic basement found only in the southwest of the region in Pembrokeshire (Fig. 1). The Neoproterozoic basement to the Eastern England Caledonides, referred to as the Fenland Terrane (Pharaoh \& Carney, 2000), is known only from boreholes. It is likewise believed to comprise a CambrianDevonian basin fill succession overlying Late Neoproterozoic basement (Verniers et al., 2002).

The Neoproterozoic igneous rocks of the WBM range in age from ca. $700 \mathrm{Ma}$ to $c a .550$ Ma (Pharaoh and Carney, 2000). The two main phases are ca. 620-590 Ma and ca. 575550 Ma (Compston et al., 2002), but earlier magmatism is known from the Johnston 
Complex of the Cymru Terrane (ca. 640 Ma: Patchett and Jocelyn, 1979), the Malverns Complex (ca. 670-677 Ma: Thorpe et al., 1984; Tucker and Pharaoh, 1991), and the Stanner Hanter Complex (ca. 702-711 Ma: Patchett et al., 1980; Schofield et al., 2010), both from the Wrekin Terrane.

Caledonian magmatism is also a feature of the WBM. Most of the Caledonian igneous rocks, which include both intrusive and extrusive varieties, are older than $440 \mathrm{Ma}$, with the great majority in the 440-480 Ma range (Noble et al., 1993; Stephenson and Highton, 2000). The main exception is the Skomer Volcanic Group of southwest Wales, which extends into the Llandovery and includes rocks of acidic composition that are potential sources of zircon (Ziegler et al., 1969). Further afield, but also on the WBM, magmatism is known to extend until ca. $430 \mathrm{Ma}$ (Llandovery) in the Brabant area of Belgium, on the basis of U-Pb zircon dating (Linnemann et al., 2012).

Although some elements of the zircon populations in the Morridge Formation can be matched with basement ages of WBM rocks, the great majority of the zircons have ages that are not represented in the WBM basement, and must therefore have been recycled from later sedimentary successions that incorporate material exotic to the area. The key components indicating an exotic origin are (i) the zircons that are younger than those known from the WBM (ca. $430 \mathrm{Ma}$ ), and (ii) the mid-Proterozoic (ca. 900-2000 Ma) grains (Figs. 6a, 6b, 7).

The closest potential source area for the $c a$. 400-430 Ma zircons is the Caledonide Orogen north of the Iapetus Suture, where there is a record of granitic and alkaline magmatism from ca. $470 \mathrm{Ma}$ to ca. $390 \mathrm{Ma}$ (Stephenson and Highton, 2000). It is not possible to determine whether the pre-430 Ma zircons in the Morridge Formation are locally derived from the WBM, or more distally from the Caledonides to the north, although it is likely that the latter provided at least some of them, given that this region must have also supplied the post-430 Ma zircons.

The basement of the WBM appears to lack any rocks with crystallisation ages older than ca. $700 \mathrm{Ma}$, although the Malverns Complex contains a range of inherited midProterozoic zircon ages with a main group dated as ca. 1600 Ma (Tucker and Pharaoh, 1991; Strachan et al., 2007). An older Precambrian prehistory for the WBM is also indicated by $\mathrm{T}_{\mathrm{DM}} \mathrm{Nd}$ model ages for Caledonian rocks that range back to ca. $1500 \mathrm{Ma}$ (Noble et al., 1993). Despite the evidence for a limited pre-700 Ma history on the WBM, 
an alternative source for the mid-Proterozoic and minor Archaean zircons is required. The wide range of mid-Proterozoic zircons strongly suggests derivation from an older sedimentary succession, and the peaks at ca. 1000-1100 Ma and 1600-1700 Ma (Fig. 8) indicate the involvement of zircons formed during the Grenvillian and Gothian orogenies. Derivation from a combination of Moine and Dalradian metasediments, both of which display wide-ranging zircon ages through the mid-Proterozoic and include strong representations of Grenvillian- and Gothian-age zircons (Cawood et al., 2003, 2004), is considered likely, although derivation from similar metasedimentary successions elsewhere in the Caledonian fold belt cannot be ruled out. The minor Archaean component could have been sourced indirectly, for example from the Dalradian of Scotland (Cawood et al., 2003) or Ireland (Clift et al., 2009; Yin et al., 2012), or directly, from the Lewisian Gneiss Complex of NW Scotland (Kinny et al., 2005).

The combination of zircons younger than $\sim 430 \mathrm{Ma}$ and a wide-ranging mid-Proterozoic zircon population with strong Grenvillian and Gothian elements strongly indicates that the Caledonian Orogen of Scotland or Ireland were major contributors of the exotic material fed to the WBM and then recycled northwards to form the Morridge Formation sandstones. This sediment must have been supplied to the WBM in the Middle or Late Devonian, since the youngest reliably-dated zircon in the Morridge Formation is $403 \pm 5$ Ma. Hence, it appears most likely that the Morridge Formation sandstones were recycled from Upper ORS sandstones, which were themselves fed from the Caledonides of northern Scotland or adjacent areas.

To test the possibility of Upper ORS recycling, two samples from the Merevale 2 Borehole were included in the analytical programme. The resulting zircon spectra (Fig. 6a) firstly demonstrate a marked difference in provenance characteristics between the two samples, with the older sample (Member 1 of Bridge et al., 1988) having a spectrum dominated by the early Palaeozoic (including zircons younger than $430 \mathrm{Ma}$ ) and the younger sample (Member 4 of Bridge et al., 1988) having an assemblage dominated by the mid-Proterozoic, with a similar range of ages to that present in the Morridge Formation of the Ipstones-Combes Valley area. The contrasting nature of the zircon populations supports previous evidence for differences in provenance on the basis of garnet geochemistry (Hallsworth et al., 2000, fig. 4).

Although the dataset is small and therefore unlikely to be fully representative of the provenance of the Upper ORS, the results indicate that recycling of the Upper ORS could 
provide the observed zircon age patterns seen in the Morridge Formation. Furthermore, variations in supply from different parts of the Upper ORS stratigraphy could generate the observed differences between the eastern (Duffield) and the western (Ipstones Edge and Combes Valley) areas, with the eastern area having a larger proportion of sediment derived from sandstones similar to those of Member 1 and the western area having a greater input from sandstones with Member 4 characteristics. On the evidence of the two samples included in this study, it is evident that provenance studies of the ORS of England and Wales would be greatly enhanced by $\mathrm{U}-\mathrm{Pb}$ analysis of detrital zircon populations.

In many Morridge Formation samples, the Neoproterozoic zircon ages correspond reasonably closely with known magmatic events on the WBM (Figs. 6a and 6b), indicating that this part of the zircon population could have been derived from local sources. The ORS Member 1 sample from the Merevale 2 Borehole also has zircons corresponding to these events (Fig. 6a), so it is possible that the late Neoproterozoic zircons in the Morridge Formation were recycled from the Upper ORS. It is also possible that they were recycled from older sandstones, since the Wrekin Quartzite (Cambrian) contains zircons derived from the Neoproterozoic of the WBM (Murphy et al., 2004).

However, a small number of samples have a group of Cambrian zircons in the ca. 510540 Ma range, most conspicuous in some of the Hurdlow and Minn sandstones in the Duffield and Ipstones Edge boreholes (Fig. 6a). This group cannot be readily related to a source either on the WBM or to a distal northern source. Therefore, this zircon group must also be exotic, but not of ultimate northern derivation. As discussed above, the WBM is part of Avalonia, which is one of a number of peri-Gondwanan terranes that faced an open ocean along the northern margin of Gondwana during the Cambrian (Murphy et al., 2004). The ca. 510-540 Ma zircons may have been derived from such terranes. For example, although most of the granitoid magmatism related to the Cadomian Orogeny of northern France and the Channel Islands ceased by ca. $570 \mathrm{Ma}$ (Miller et al., 2001), there are records of younger magmatism in the St Malo Terrane at ca. 540 Ma and in the Mancellian Terrane at ca. 525 Ma (Jonin and Vidal, 1975; Peucat, 1986; Brown et al., 1990; Brown, 1996). Another possible source area for these zircons is Thuringerwald (part of Saxothuringia), where magmatic rocks dated as 530-541 Ma are known (Verniers et al., 2002). However, this region is currently located at a considerable distance from the UK part of the WBM, requiring a long and possibly unlikely transport pathway. 


\subsection{Rough Rock south lobe (Yeadonian)}

Across most of the Central Pennine Basin, the Rough Rock has all the typical features of northerly-derived Namurian sediment (Hallsworth et al., 2000; Hallsworth and Chisholm, 2008), including a garnet assemblage comprising low-Ca, high-Mg garnet and a zircon spectrum with a well-defined early Palaeozoic peak, a range of mid-Proterozoic ages, and a small Archaean group (Fig. 8). However, the higher quartz:feldspar ratios associated with the south lobe of the Rough Rock indicate involvement of a different source, interpreted as lying on the WBM to the south (Bristow, 1988; Bristow, 1993).

Heavy mineral and palaeocurrent data from a section in this 'south lobe' of the Rough Rock at Coxbench (Fig. 2) were presented by Hallsworth and Chisholm (2008, fig. 13). The palaeocurrent direction was from east to west throughout. However, some samples (Fig. 9, samples A and B) have purely 'northern' heavy mineral signatures, with high monazite:zircon ratios, whereas others have lower monazite:zircon ratios, and some contain chrome spinel, which is rare in northerly-derived Namurian sediment. One sample (G) proved to contain a bimodal garnet population with groups of high-Ca, highMg grains and high-Mn, low-Mg grains (Hallsworth and Chisholm, 2008, fig. 11). This garnet assemblage deviates markedly from those of typical northern origin, which are dominated by high-Mg, low-Ca types (Hallsworth et al., 2000; Hallsworth and Chisholm, 2008), and was interpreted as showing that some of the sediment was derived from the WBM. The variability of the heavy mineral suites at this locality was taken to indicate mixing of northern and southern sediment in different proportions, within the context of a river system flowing from east to west along the northern side of the WBM.

The sample included in this study is also from the Coxbench locality (Fig. 9), about $0.5 \mathrm{~m}$ above the level of sample $G$ of Hallsworth and Chisholm (2008). It has a bimodal garnet population that closely resembles that obtained from sample $G$, and therefore has features that contrast with Millstone Grit sandstones of northern derivation. Despite this, the zircon spectrum (Fig. 6b) has a similar overall aspect to that previously obtained from the main Rough Rock (Fig. 8) by Hallsworth et al. (2000). Both samples have a large early Palaeozoic peak, a wide range of mid-Proterozoic grains and a small number of Archaean zircons. There are some differences in detail, in that the south lobe sample has an older Palaeozoic peak at ca. 435 Ma compared with $c a .420$ Ma in the main lobe, and the main 
lobe appears to have a higher proportion of mid-Proterozoic grains, but nevertheless, both samples have typical ‘northern’ zircon provenance characteristics.

The zircon U-Pb analysis failed to identify any late Neoproterozoic and Cambrian zircons that would indicate involvement of WBM basement rocks in sourcing the Rough Rock south lobe. It is possible that the exclusively northern zircon character of the sample was inherited from recycled Upper ORS on the WBM. However, for this to be the case, the nature of the recycled ORS must have been different to that analysed from Merevale-2, since the zircon populations in the Upper ORS of Merevale-2 contain a small late Neoproterozoic-Cambrian component (Fig. 6a).

In summary, zircon age data have neither proved nor disproved involvement of the WBM as a provenance component of the Rough Rock south lobe. Heavy mineral and garnet data from the Coxbench locality clearly indicate the presence of one source component with typical 'northern' character and another with features that indicate a different origin. It is possible that the source of this second component lay on the WBM, but consisted exclusively of ORS sediment originally shed from the Caledonides. This explanation would satisfy the heavy mineral and garnet geochemical evidence. Alternatively, since the zircon ages are entirely 'northern' in character, the detritus may have been introduced entirely from the north, but not through the transport system that supplied the main lobe of the Rough Rock. More extensive zircon provenance studies of the ORS in the English Midlands are required before the recycling possibility can be adequately tested.

\subsection{Ludgbridge Conglomerate (Langsettian)}

The main peak in the zircon population in the Ludgbridge Conglomerate is at ca. $640 \mathrm{Ma}$ (Fig. 6b). Although this lies within the overall range of late Neoproterozoic magmatic activity on the WBM, the only intrusive body known to directly correspond is the Johnston Plutonic Complex, which is dated as $643 \mathrm{Ma}$ (Patchett and Jocelyn, 1979). This body is located a considerable distance to the southwest, on the southern margin of the WBM, and it seems unlikely that it could have been the source for the Ludgbridge Conglomerate, which appears to be a relatively proximal deposit. The data from the Ludgbridge Conglomerate, therefore, suggest either that there are correlative igneous intrusions on the WBM (but as yet undiscovered or inadequately dated), or that the Ludgbridge Conglomerate zircons were recycled from older sandstones that were themselves sourced from the Johnston Pluton or equivalent intrusive rocks. Possible 
candidate sandstones are the Silurian submarine fan sandstones of the Welsh Basin (Cymru Terrane), which were derived from the south (in the direction of the Johnston Plutonic Complex) on palaeocurrent evidence (Davies et al., 1997). Although conventional heavy mineral data have been acquired from these sandstones (Morton et al., 1992), zircon age data are not available to test this possibility. The possibility of direct supply from the Johnston Pluton could also be tested by analysing zircons from Carboniferous sandstones of Pembrokeshire, which were deposited on the southern margin of the WBM adjacent to this igneous complex. Since ongoing studies (unpublished) have not revealed a major ca. 640 Ma zircon group in this area, it seems unlikely that the pluton contributed directly to the Ludgbridge Conglomerate.

There is a small number of mid-Proterozoic and Archaean zircons in the sample (Fig. 6b), suggesting that limited recycling of northerly-derived sediment played a part in the Ludgbridge Conglomerate provenance. There is also a small group of Cambrian zircons similar in age to those found in the Minn and Hurdlow sandstones, and a similar recycled Cadomian provenance is considered most likely.

\subsection{Top Hard Rock (Duckmantian)}

Palaeocurrent and heavy mineral evidence from the Top Hard Rock indicates derivation from a western transport system, with a contribution from a southern source, inferred to be the WBM (Chisholm and Hallsworth, 2005). The zircon age spectrum includes a large group of Neoproterozoic to Cambrian zircons comparable to that seen in other samples of WBM origin. Given the palaeocurrent evidence for a source to the west, it is possible that some of the zircons in this age range were derived from the Monian Composite Terrane of Anglesey. The largest cluster of zircons in this group lies in the ca. 610-620 Ma range, coeval with the Coedana Granite (Tucker and Pharaoh, 1991), and some of the older zircons may be derived from the Coedana Gneiss, dated as 666 \pm 7 Ma (Strachan et al., 2007).

The zircon data also provide some insights into the location of the western source. The zircon spectrum is distinctive in containing a significant proportion of zircons younger than $400 \mathrm{Ma}$, the youngest being $369 \mathrm{Ma}$. Furthermore, the early Palaeozoic part of the spectrum is bimodal, with an older group in the ca. 460-490 Ma range and a younger group peaking in the $c a$. 380-410 Ma range. These events can be readily related to magmatism in the Irish Caledonides. The older group is equivalent to magmatic rocks 
associated with the Grampian phase of the Caledonian Orogeny, which are dated between $463 \mathrm{Ma}$ and 493 Ma (Friedrich et al., 1999; Draut et al., 2009). The younger group appears to span the range of the post-collisional Irish Caledonide granites: for example, the Galway Granite shows a long range of activity from $c a .420 \mathrm{Ma}$ to $c a .380 \mathrm{Ma}$ (Buchwaldt et al., 2001; Feely et al., 2003, 2011), and the initial emplacement of the Donegal Granite is dated as $428 \mathrm{Ma}$ (Condon et al., 2004). The scattered nature of the mid-Proterozoic part of the zircon spectrum suggests recycling from earlier sedimentary successions. A potential candidate is the Irish Ordovician succession, which contains a similar range of mid-Proterozoic ages (Mange et al., 2010). In summary, much of the zircon spectrum can be attributed to an Irish Caledonide source, supplemented by Late Neoproterozoic zircons from either the Monian Composite Terrane of Anglesey or the WBM. However, involvement of a more distal western source, as proposed by Rippon (1996), cannot be ruled out since Newfoundland and New England have a similar record of post-collisional magmatism to western Ireland (Kerr, 1997; Bradley et al., 2000; Whalen et al., 2006; Feely et al., 2011).

\subsection{Contemporaneous Carboniferous magmatism}

None of the samples analysed in this study contain zircons of Early Carboniferous age, despite the evidence for volcanic activity of this age on the WBM. For example, Early Carboniferous magmatic activity is recorded by the Little Wenlock Lavas, lavas in the Bristol-Weston-super-Mare, Derbyshire and the Vale of Belvoir (East Midlands) areas, and the Golden Hill Vent (Waters, 2003; Carney et al., 2004). The absence of Early Carboniferous zircons probably reflects the composition of these magmatic rocks, which are all mafic and therefore unlikely to supply significant amounts of zircon.

\section{CONCLUSIONS}

Detrital zircon dating has provided new insights into the origin of Namurian and Westphalian sandstones known or believed to have been shed from the WBM into the Central Pennine Basin (Fig. 10). Most of the zircons in the quartzitic sandstones of the Pendleian-Marsdenian Morridge Formation cannot be related to basement rocks forming the WBM, indicating that most of the detritus forming these sandstones were recycled from older sandstones that had previously been deposited over the massif. The ultimate source of this exotic material lay in the Caledonides to the north and on the basis of the youngest reliably-dated zircon (403 $\pm 5 \mathrm{Ma}$ ) was deposited over the WBM no earlier than 
the Middle-Late Devonian. The Upper ORS in the Merevale 2 borehole (located on the WBM) has zircon age profiles indicating it was a suitable candidate source component for the Morridge Formation. The Morridge Formation also contains Late Neoproterozoic zircons that can be related to igneous basement sources on the WBM. Some samples also contain Cambrian zircons that are most likely to have originated in the Cadomian Orogen of northern France, such as the St Malo and Mancellian terranes. There are marked lateral changes in the Morridge Formation zircon populations between the east (Duffield Borehole) and the west (Ipstones Edge Borehole and Combes Valley), indicating the existence of at least two separate sediment dispersal systems tapping different areas of the WBM.

The south lobe of the Rough Rock (Yeadonian) is also believed to be derived, at least in part, from the WBM, on the basis of petrographic and heavy mineral criteria. However, a sample with heavy mineral and garnet geochemical characteristics that contrast with those of typical 'northern' origin has an exclusively Caledonide zircon age population with no record of zircons derived from Neoproterozoic basement rocks on the WBM. If the sediment source lay on the WBM, it must have consisted exclusively of detritus originally fed from the north. Alternatively, the sediment could have been introduced from the north, but not through the transport system that supplied the main lobe of the Rough Rock.

By contrast, the Langsettian Ludgbridge Conglomerate in the South Staffordshire Coalfield is dominated by zircons of Late Neoproterozoic age that correspond to the age range of Neoproterozoic igneous activity on the WBM. However, the main peak in the Ludgbridge Conglomerate zircon population is at ca. $640 \mathrm{Ma}$ : the only intrusive body with a similar age on the WBM is the ca. 643 Ma Johnston Plutonic Complex, which is located a considerable distance to the southwest. On the basis of its coarse-grained nature, the Ludgbridge Conglomerate is evidently a relatively proximal deposit, and consequently the zircon data either indicate there are, as yet, undiscovered igneous intrusions coeval with the Johnston Plutonic Complex elsewhere on the WBM, or that the Ludgbridge Conglomerate zircons were recycled from older sandstones that were themselves sourced from the Johnston Pluton or equivalent intrusive rocks.

The Duckmantian Top Hard Rock has palaeocurrents and heavy mineral assemblages that indicate derivation from a western transport system, but with a contribution from a southern source, inferred to be the WBM. The zircon population includes a Late 
Neoproterozoic component that is consistent with input from the WBM, including the Monian Composite Terrane of Anglesey. The zircon population in the Top Hard Rock is distinctive in containing a large group of grains younger than $400 \mathrm{Ma}$, the youngest being $369 \mathrm{Ma}$, together with an older group of grains in the ca. 460-490 Ma range. These features are consistent with input from the Irish Caledonides, and agree with the palaeocurrent evidence, although a more distal source in Newfoundland and New England cannot be ruled out.

The results of this study reinforce the importance of integrating as many techniques as possible when interpreting sandstone provenance. In the absence of palaeocurrent data, petrographic information and heavy mineral evidence, the zircon data from Namurian sandstones in the southern part of the Central Pennine Basin could have been erroneously interpreted as indicating much of the sediment was shed directly from the north. The integration of zircon evidence has greatly enhanced the understanding of the provenance history of these sandstones by showing the majority of the sediment was recycled from Upper ORS sandstones that were originally deposited over the WBM in a previous phase of large-scale sediment supply from the Caledonian belt to the north.

\section{ACKNOWLEDGEMENTS}

We are grateful to Dr T.J. Pharaoh, Dr. S. Tyrrell and Dr D. Sahy for their constructive comments on an earlier version of this manuscript. The contribution of CW is included with the permission of the Executive Director, British Geological Survey (NERC).

\section{REFERENCES}

Aitkenhead, N. 1977. The Institute of Geological Sciences borehole at Duffield, Derbyshire. Bulletin of the Geological Survey of Great Britain 59, 1-35.

Aitkenhead, N., Chisholm, J.I., Stephenson, I.P. 1985. Geology of the country around Buxton, Leek and Bakewell. Memoir of the Geological Survey of Great Britain, Sheet 111 (England and Wales).

\section{Aitkenhead, N., Barclay, W.J., Brandon, A., Chadwick, R.A., Chisholm, J.I., Cooper, A.H., Johnson, E.W. (eds) 2002. British regional geology: The Pennines and adjacent areas. HMSO for the British Geological Survey, London.}

Besly, B.M. 1988. Palaeogeographic implications of late Westphalian to ealy Permian red-beds, central England. In Sedimentation in a synorogenic basin complex: the Upper 
Carboniferous of northwest Europe, Besly BM, Kelling G. (eds). Blackie, Glasgow and London, 200-221.

Black, L,P,, Kamo, S.L., Allen, C.M., Aleinikoff, J.N., Davis, D.W., Korsch, R.J., Foudoulis, C. 2003. TEMORA 1: a new zircon standard for Phanerozoic U-Pb geochronology. Chemical Geology 200, 155-170.

Bradley, D.C., Tucker, R.D., Lux, D.R., Harris, A.G., McGregor, D.C. 2000. Migration of the Acadian Orogen and foreland basin across the northern Appalachians of Maine and adjacent areas. U.S. Geological Survey Professional Paper 1624, 49 pp.

Bridge, D.M., Carney, J.N.C., Lawley, R.S., Rushton, A.W.A. 1998. Geology of the country around Coventry and Nuneaton. Memoir of the British Geological Survey, Sheet 169 (England and Wales).

Bristow, C.S. 1988. Controls on the sedimentation of the Rough Rock Group (Namurian) from the Pennine Basin of northern England. In Sedimentation in a synorogenic basin complex: the Upper Carboniferous of northwest Europe, Besly, B.M., Kelling, G. (eds). Blackie, Glasgow and London, 114-131.

Bristow, C.S. 1993. Sedimentology of the Rough Rock: a Carboniferous braided river sheet sandstone in northern England. In Braided Rivers, Best, J.L., Bristow, C.S. (eds). Geological Society, London, Special Publication 75, 291-304.

Brown, M. 1996. The Late Precambrian dynamic evolution of the Armorican segment of the Cadomian belt: distortion of an active continental margin during south-west directed convergence and subduction of a bathymetric high. Géologie de la France 3, 3-22.

Brown, M., Power, G.M., Topley, C.G., D’Lemos, R.S. 1990. Cadomian magmatism in the North Armorican Massif. In The Cadomian Orogeny, D’Lemos, R.S., Strachan, R.A., Topley CG. (eds). Geological Society, London, Special Publication 51, 81-213.

Buchwaldt, R., Kroner, A., Feely, M., Todt, W., Toulkerides, T. 2001. Geochronology and $\mathrm{Nd}-\mathrm{Sr}$ systematics of Late Caledonian granites in western Ireland: new implications for the Caledonian orogeny. Geological Society of America Abstracts with Programs 33(1): A32.

Carney, J.N., Ambrose, K., Brandon, A., Royles, C.P., Lewis, M.A., Sheppard, H. 2004. Geology of the country around Melton Mowbray. Sheet Description of the British Geological Survey, 1:50 000 Series Sheet 142 Loughborough (England and Wales).

Cawood, P.A., Nemchin, A.A., Smith, M., Loewy, S. 2003. Source of the Dalradian Supergroup constrained by U-Pb dating of detrital zircon and implications for the East Laurentian margin. Journal of the Geological Society, London 160, 231-246. 
Cawood, P.A., Nemchin, A.A., Strachan, R.A., Kinny, P.D., Loewy, S. 2004.

Laurentian provenance and an intracratonic tectonic setting for the Moine Supergroup, Scotland, constrained by detrital zircons from the Loch Eil and Glen Urquhart successions. Journal of the Geological Society, London 161, 861-874.

Chisholm, J,I. 1990. The Upper Band-Better Bed sequence (Lower Coal Measures, Westphalian A) in the central and south Pennine area of England. Geological Magazine 127, 55-74.

Chisholm, J,I,, Hallsworth, C,R. 2005. Provenance of Upper Carboniferous sandstones in east Derbyshire: role of the Wales-Brabant High. Proceedings of the Yorkshire Geological Society 55, 205-233.

Chisholm, J.I., Waters, C.N. 2012. Syn-sedimentary deformation of the Ashover Grit (Namurian: Marsdenian Substage) deltaic succession around Wirksworth, Derbyshire, UK. Proceedings of the Yorkshire Geological Society 59, 25-36.

Chisholm, J.I., Charsley, T.J., Aitkenhead, N. 1988. Geology of the country around Ashbourne and Cheadle. Memoir of the British Geological Survey, Sheet 124 (England and Wales).

Chisholm, J.I., Waters, C.N., Hallsworth, C.R., Turner, N., Strong, G.E., Jones, N.S. 1996. Provenance of Lower Coal Measures around Bradford, West Yorkshire. Proceedings of the Yorkshire Geological Society 51, 153-166.

Cliff, R,A,, Drewery, S,E, Leeder, M,R. 1991. Sourcelands for the Carboniferous Pennine river system: constraints from sedimentary evidence and U-Pb geochronology using zircon and monazite. In Developments in Sedimentary Provenance Studies, Morton, A.C., Todd, S.P., Haughton, P.D.W. (eds). Geological Society, London, Special Publication 57, 137-159.

Clift, P.D., Carter, A., Draut, A.E., Van Long, H., Chew, D., Schouten, H.A. 2009. Detrital U-Pb zircon dating of lower Ordovician syn-arc-continent collision conglomerates in the Irish Caledonides. Tectonophysics, 479, 165-174.

Collinson, J.D. 1988. Controls on Namurian sedimentation in the Central Province basins of northern England. In Sedimentation in a Synorogenic Basin Complex, Besly, B.M., Kelling, G. (eds). Blackie, Glasgow and London, 85-101.

Compston, W., Wright, A.E., Toghill, P. 2002. Dating the Late Precambrian volcanicity of England and Wales. Journal of the Geological Society, London 159, 323339.

Condon, D.J., Bowring, S.A., Pitcher, W.S., Hutton, D.W.H. 2004. Rates and tempo of granitic magmatism; a U-Pb geochronological investigation of the Donegal Batholith (Ireland). Geological Society of America Abstracts with Programs, 36(5), 406. 
Davies, J.R., Fletcher, C.J.N., Waters, R.A., Wilson, D., Woodhall, D.G.,

Zalasiewicz, J.A. 1997. Geology of the country around Llanilar and Rhayadar. Memoir of the British Geological Survey, England and Wales, Sheets 178 and 179 (England and Wales).

Draut, A.E., Clift, P.D., Amato, J.M., Blusztajn, J., Schouten, H. 2009. Arc-continent collision and the formation of continental crust: a new geochemical and isotopic record from the Ordovician Tyrone Igneous Complex, Ireland. Journal of the Geological Society, London 166, 485-500.

Evans, J.A., Chisholm, J.I., Leng, M.J. 2001. How U-Pb detrital monazite ages contribute to the interpretation of the Pennine Basin infill. Journal of the Geological Society, London 158, 741-744.

Feely, M., Coleman, D., Baxter, S., Miller, B. 2003. U-Pb zircon geochronology of the Galway Granite, Connemara, Ireland: implications for the timing of late Caledonian tectonic and magmatic events and for correlations with Acadian plutonism in New England. Atlantic Geology 39, 175-184.

Feely, M., Selby, D., Hunt, J., Conliffe, J. 2011. Long-lived granite-related molybdenite mineralization at Connemara, western Irish Caledonides. Geological Magazine 147, 886894.

Friedrich, A.M., Bowring, S.A., Martin, M.W., Hodges, K.V. 1999. Short-lived continental magmatic arc at Connemara, western Irish Caledonides: Implications for the age of the Grampian orogeny. Geology 27, 27-30.

Gilligan, A. 1920. The petrography of the Millstone Grit of Yorkshire. Quarterly Journal of the Geological Society, London 75, 251-293.

Glover, B.W., Leng, M.J., Chisholm, J.I. 1996. A second major fluvial sourceland for the Silesian Pennine Basin of northern England. Journal of the Geological Society, London 153, 901-906.

Hallsworth, C.R., Chisholm, J.I. 2000. Stratigraphic evolution of provenance characteristics in Westphalian sandstones of the Yorkshire coalfield. Proceedings of the Yorkshire Geological Society 53, 43-72.

Hallsworth, C.R., Chisholm, J.I. 2008. Provenance of late Carboniferous sandstones in the Pennine Basin (UK) from combined heavy mineral, garnet geochemistry and palaeocurrent studies. Sedimentary Geology 203, 196-212.

Hallsworth, C.R., Morton, A.C., Claoué-Long, J.C., Fanning, C.M. 2000.

Carboniferous sand provenance in the Pennine Basin, UK: constraints from heavy mineral and SHRIMP zircon age data. Sedimentary Geology 137, 147-185. 
Jonin, M., Vidal, P. 1975. Etude géochronologique des granitoids de la Mancellia, Massif Armoricain, France. Canadian Journal of Earth Sciences, 12, 920-927.

Kerr, A. 1997. Space-time composition relationships among Appalachian-cycle plutonic suites in Newfoundland. Memoir of the Geological Society of America 191, 193-220.

Kinny, P.D., Friend, C.R.L., Love, G.J. 2005. Proposal for a terrane-based nomenclature for the Lewisian Gneiss Complex of NW Scotland. Journal of the Geological Society, London 162, 175-186.

Leeder, M.R. 1988. Devono-Carboniferous river systems and sediment dispersal from the orogenic belts and cratons of NW Europe. In The Caledonian-Appalachian Orogen, Harris, A.L., Fettes, D.J. (eds). Geological Society, London, Special Publication, 38, 549-558.

Linnemann, U., Herbosch, A., Liégeois, J.-P., Pin, C., Gärtner, A., Hofmann, M. 2012. The Cambrian to Devonian odyssey of the Brabant Massif within Avalonia: a review with new zircon ages, geochemistry, Sm-Nd isotopes, stratigraphy and palaeogeography. Earth-Science Reviews, 112, 126-154.

Ludwig, K.R. 2001. SQUID 1.02, A User's Manual. Berkeley Geochronology Center Special Publication 2. Berkeley, CA 94709, USA.

Ludwig, K.R. 2003. Isoplot/Ex version 3.0: A geochronological toolkit for Microsoft Excel. Berkeley Geochronology Center Special Publication 4. Berkeley, CA 94709, USA.

Mange, M., Idleman, B., Yin, Q.-Z., Hidaka, H., Dewey. J. 2010. Detrital heavy minerals, white mica and zircon geochronology in the Ordovician South Mayo Trough, western Ireland: signatures of the Laurentian basement and the Grampian orogeny. Journal of the Geological Society, London 167, 1147-1160.

Miller, B.V., Samson, S.D., D’Lemos, R.S. 2001. U-Pb geochronological constraints on the timing of plutonism, volcanism, and sedimentation, Jersey, Channel Islands, UK. Journal of the Geological Society, London 158, 243-252.

Morton, A.C., Davies, J.R., Waters, R.A. 1992. Heavy minerals as a guide to turbidite provenance in the Lower Palaeozoic Southern Welsh Basin: a pilot study. Geological Magazine 129, 573-580.

Murphy, J.B., Fernández-Suárez, J., Jeffries, T.E., Strachan, R.A. 2004. U-Pb (LAICP-MS) dating of detrital zircons from Cambrian clastic rocks in Avalonia: erosion of a Neoproterozoic arc along the northern Gondwanan margin. Journal of the Geological Society 161, 243-254. 
Noble, S.R., Tucker, R.D., Pharaoh, T.C. 1993. Lower Palaeozoic and Precambrian igneous rocks from eastern England, and their bearing on late Ordovician closure of the Tornquist Sea: constraints from U-Pb and Nd isotopes. Geological Magazine 130, 835846.

Paces, J.B., Miller, J.D. 1993. Precise U-Pb ages of Duluth Complex and related mafic intrusions, northeastern Minnesota: geochronological insights to physical, petrogenetic, paleomagnetic, and tectonomagmatic process associated with the $1.1 \mathrm{Ga}$ Midcontinent Rift System. Journal of Geophysical Research 98, 13997-14013.

Patchett. P.J., Jocelyn, J. 1979. U-Pb zircon ages for late Precambrian igneous rocks in South Wales. Journal of the Geological Society, London 136, 13-19.

Patchett, P.J., Gale, N.H., Goodwin, R., Humm, M.J. 1980. Rb-Sr whole-rock isochron ages of late Precambrian to Cambrian igneous rocks from southern Britain. Journal of the Geological Society, London 137, 649-656.

Peucat, J.J. 1986. Behaviour of Rb-Sr whole rock and U-Pb zircon systems during partial melting as shown in migmatitic gneisses from the St Malo Massif, NE Brittany, France. Journal of the Geological Society, London 147, 876-886.

Pharaoh, T.C., Carney, J.N. 2000. Introduction to the Precambrian rocks of England and Wales. In Precambrian Rocks of England and Wales, Carney, J.N., Horak, J.M., Pharaoh, T.C., Gibbons, W., Wilson, D., Barclay, W.J., Bevins, R.E., Cope, J.C.W., Ford, T.D. (eds). Geological Conservation Review Series 20, 1-17.

Pharaoh, T.C., Brewer, T.S., Webb, P.C. 1993. Subduction related magmatism of late Ordovician age in Eastern England. Geological Magazine 130, 647-656.

Rippon, J.H. 1996. Sand body orientation, palaeoslope analysis and basin-fill implications in the Westphalian A-C of Great Britain. Journal of the Geological Society, London 153, 881-900.

Schofield, D.I., Millar, I.L., Wilby, P.R., Evans, J.A. 2010. A new, high precision U$\mathrm{Pb}$ date from the oldest known rocks in southern Britain. Geological Magazine 147, 145150 .

Soper, N.J., Woodcock, N.H. 2003. The lost Lower Old Red Sandstone of England and Wales: a record of post-Iapetan flexure or Early Devonian transtension? Geological Magazine 140, 627-647.

Stephenson, D., Highton, A.J. 2000. Caledonian igneous rocks of Great Britain: an introduction. In Caledonian Igneous Rocks of Great Britain, Stephenson, D., Bevins, R.E., Millward, D., Stone, P., Parsons, I., Highton, A.J., Wadsworth, W.J. (eds).

Geological Conservation Review Series 17, 1-28. 
Strachan, R.A., Collins, A.S., Buchan, C., Nance, R.D., Murphy, J.B., D’Lemos, R.S. 2007. Terrane analysis along a Neoproterozoic active margin of Gondwana: insights from U-Pb zircon geochronology. Journal of the Geological Society, London 164, 57-60.

Stuart, F.M., Bluck, B.J., Pringle, M.S. 2001. Detrital muscovite ${ }^{40} \mathrm{Ar} /{ }^{39} \mathrm{Ar}$ ages from Carboniferous sandstones of the British Isles: provenance and implications for the uplift history of orogenic belts. Tectonics 20, 255-267.

Taylor, K., Rushton, A.W.A. 1971. The pre-Westphalian geology of the Warwickshire Coalfield, with a description of three boreholes in the Merevale area. Bulletin of the Geological Survey of Great Britain 35.

Tera, F., Wasserburg, G. 1972. U-Th-Pb systematics in three Apollo 14 basalts and the problem of initial Pb in lunar rocks. Earth and Planetary Science Letters 14, 281-304.

Thorpe, R.S., Beckinsale, R.D., Patchett, P.J., Piper, J.A., Davies, G.R., Evans, J.A. 1984. Crustal growth and late Precambrian - early Palaeozoic plate tectonic evolution of England and Wales. Journal of the Geological Society, London 141, 521-536.

Trewin, N.H., Holdsworth, B.K. 1973. Sedimentation in the lower Namurian rocks of the North Staffordshire Basin. Proceedings of the Yorkshire Geological Society 39, 371408.

Tucker, R.D,, Pharaoh, T.C. 1991. U-Pb zircon ages for Late Precambrian igneous rocks in southern Britain. Journal of the Geological Society, London 148, 435-443.

Tyrrell, S., Haughton, P.D.W., Daly, J.S., Kokfelt, T.F., Gagnevin, D. 2006. The use of the common $\mathrm{Pb}$ isotope composition of detrital $\mathrm{K}$-feldspar grains as a provenance tool and its application to Upper Carboniferous paleodrainage, northern England. Journal of Sedimentary Research 76, 324-345.

Verniers, J., Pharaoh, T., André, L., Debacker, T.N., de Vos, W., Everaerts, M., Herbosch, A., Samuelsson, J., Sintubin, M., Vecoli, M. 2002. The Cambrian to mid Devonian basin development and deformation history of Eastern Avalonia, east of the Midlands Microcraton: new data and a review. In Palaeozoic Amalgamation of Central Europe, Winchester, J.A., Pharaoh, T.C., Verniers, J. (eds). Geological Society, London, Special Publication 201, 47-93.

Waters, C.N. 2003. Carboniferous and Permian igneous rocks of central England and the Welsh Borderland. In Carboniferous and Permian Igneous Rocks of Great Britain North of the Variscan Front, Stephenson, D., Loughlin, S.C., Millward, D., Waters, C.N., Williamson, I.T. (eds). Geological Conservation Review Series 27, 281-316.

Waters, C.N., Davies, S.J. 2006. Carboniferous extensional basins, advancing deltas and coal swamps. In: The Geology of England and Wales ( $\left.2^{\text {nd }} E d\right)$, Brenchley, P.J., Rawson, P.F. (eds). Geological Society, London, 173-223. 
Waters, C.N., Bridge, D.M., Humpage, A.J., Barclay, W.J., Smith, N.J.P. 2013. Geology of the Dudley district - a brief explanation of the geological map. Sheet Explanation of the British Geological Survey, 1:50 000 Sheet 167 Dudley (England and Wales).

Waters, C.N., Waters, R.A., Barclay, W.J., Davies, J.R. 2009. Lithostratigraphical framework for Carboniferous successions of Southern Great Britain (Onshore). British Geological Survey Research Report RR/09/01.

Whalen, J.B., McNicoll, V.J., van Staal, C.R., Lissenberg, C.J., Longstaffe, F.J., Jenner, G.A., van Breeman, O. 2006. Spatial, temporal and geochemical characteristics of Silurian collision-zone magmatism, Newfoundland Appalachians: an example of a rapidly evolving magmatic system related to slab break-off. Lithos 89, 377-404.

Whitehead, T.H., Eastwood, T. 1927. The geology of the southern part of the South Staffordshire Coalfield. Memoir of the Geological Survey of Great Britain.

Williams, I.S. 1998. U-Th-Pb geochronology by ion microprobe. In Applications of microanalytical techniques to understanding mineralising processes, McKibben, M.A., Shanks, W.C. III, Ridley, W.I. (eds). Society of Economic Geologists, Reviews in Economic Geology, 7, 1-35.

Yin, Q.-Z., Wimpenny, J., Tollstrup, D.L., Mange, M., Dewey, J.F., Zhou, Q., Li, X.H., Wu, F.-Y., Li, Q.-L., Liu, Y., Tang, G.-Q. 2012. Crustal evolution of the South Mayo Trough, western Ireland, based on U-Pb ages and Hf-O isotopes in detrital zircons. Journal of the Geological Society, London 169, 681-689.

Ziegler, A,M,, McKerrow, W.S., Burne, R.V., Baker, P.E. 1969. Correlation and environmental setting of the Skomer Volcanic Group, Pembrokeshire. Proceedings of the Geologists' Association 80, 409-439. 


\section{FIGURE CAPTIONS}

Early Namurian (Arnsbergian)

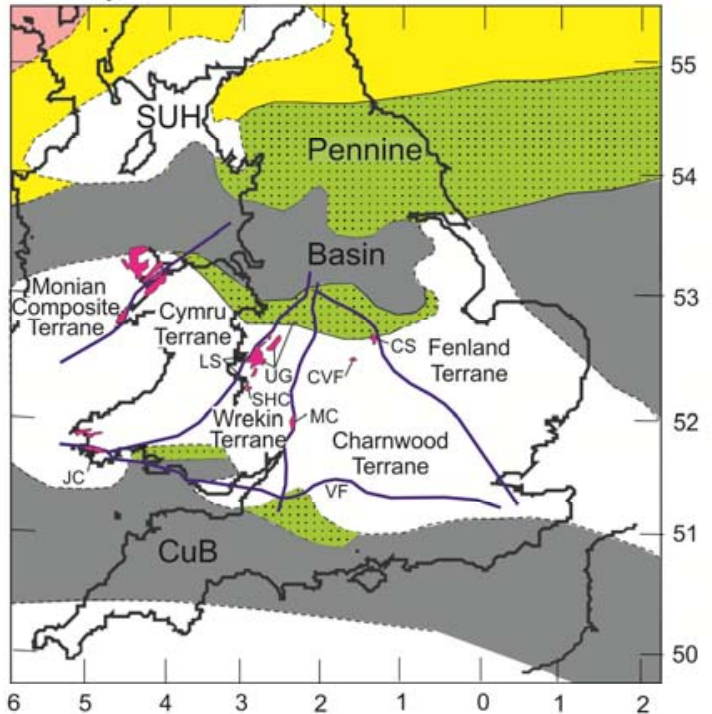

$\square$ Uplands

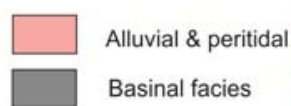

'Millstone Grit' Facies 'Yoredale' and coastal facies
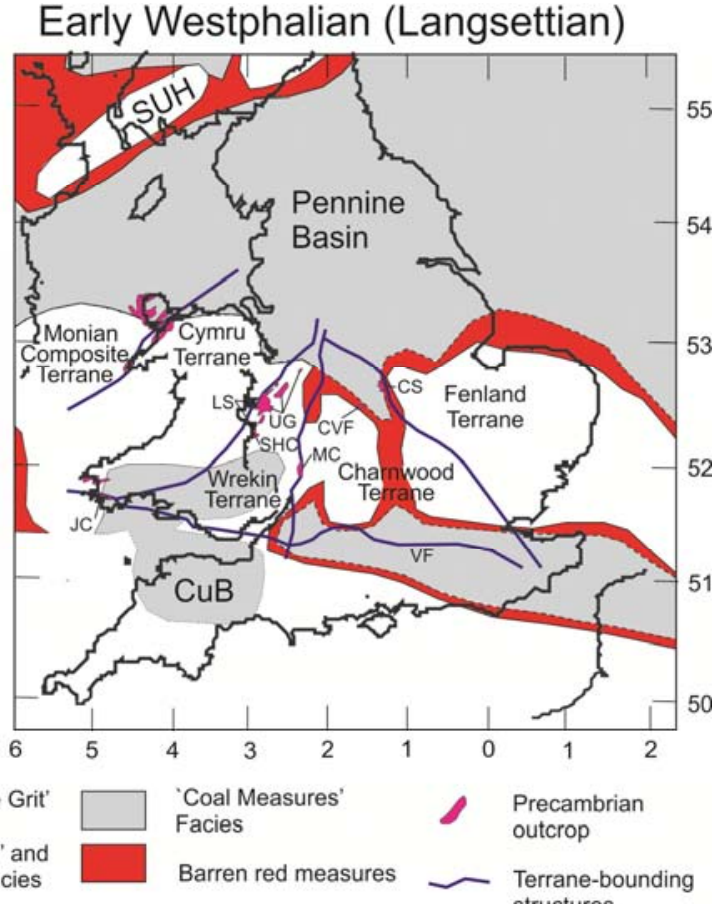

structures

Figure 1. Palaeogeographic reconstructions of the Central Pennine Basin and WalesBrabant Massif (WBM) during Arnsbergian (a) and Langsettian (b) after Waters and Davies (2006), superimposed on reconstructed Neoproterozoic terrane elements adapted from Pharaoh and Carney (2000). CS - Charnian Supergroup. CuB - Culm Basin. CVF Caldecote Volcanic Formation. JC - Johnston Complex. LS - Longmyndian Supergroup. MC - Malverns Complex. SHC - Stanner-Hanter Complex. SUH - Southern Uplands High. UG - Uriconian Group. VF - Variscan Front. 


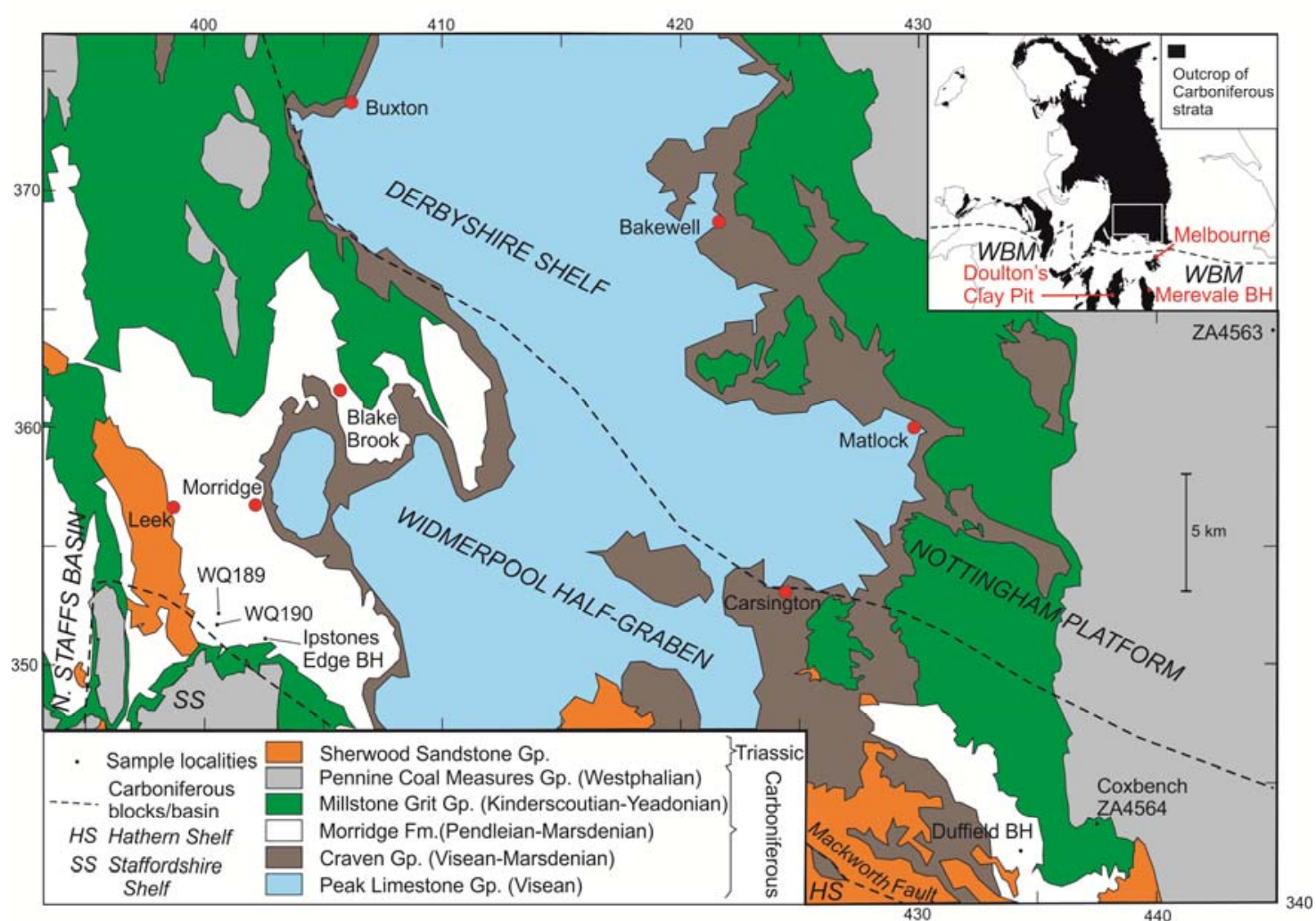

Figure 2. Location map of samples analysed in the course of this study. Bedrock geology of the study area based on BGS mapping. BGS (C) NERC 2014. 
STAFFORDSHIRE

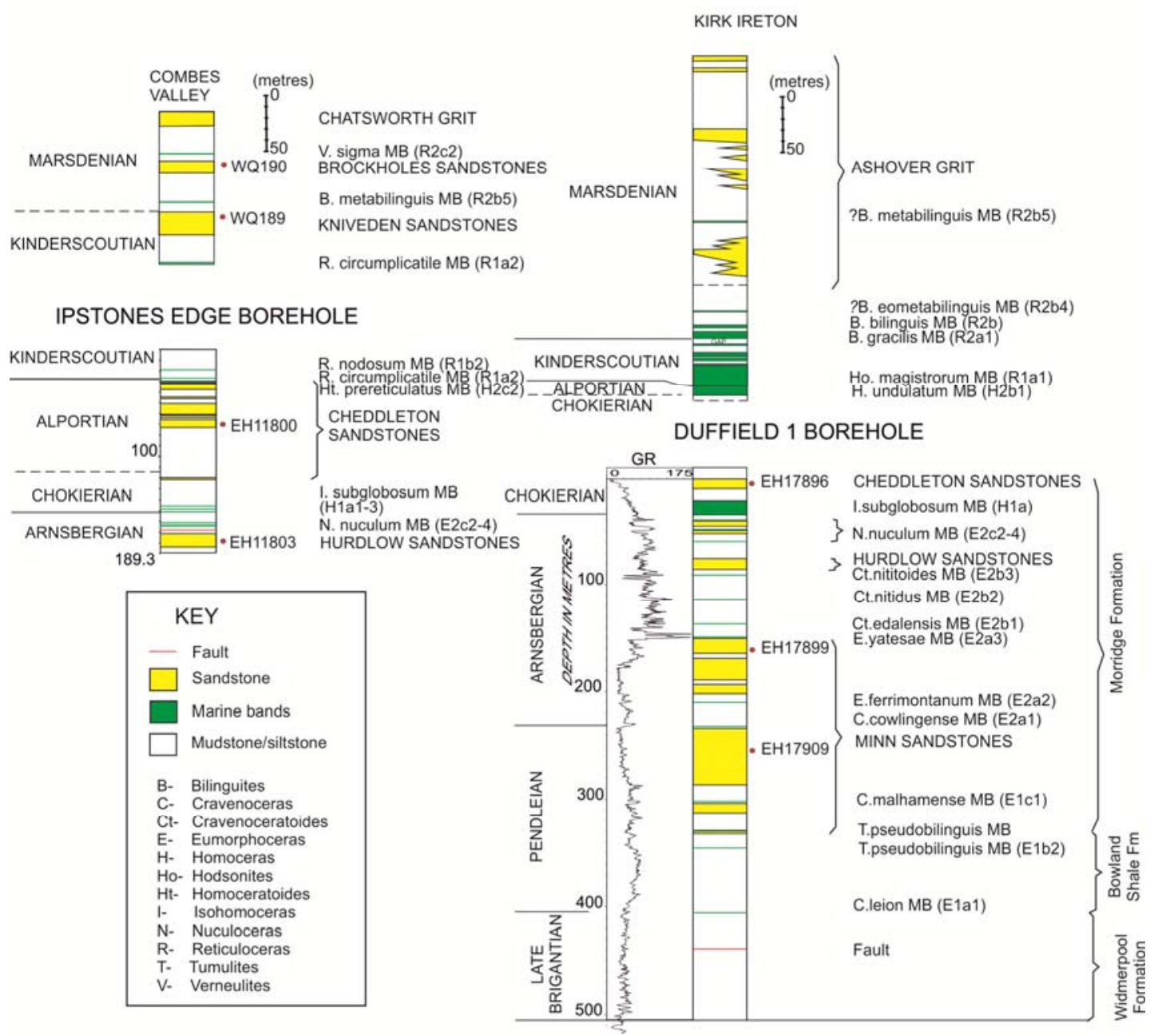

Figure 3. Stratigraphic distribution of samples of Pendleian-Marsdenian age discussed in this paper. The logs are modified from Aitkenhead (1977), Chisholm et al. (1988) and Chisholm and Waters (2012). 

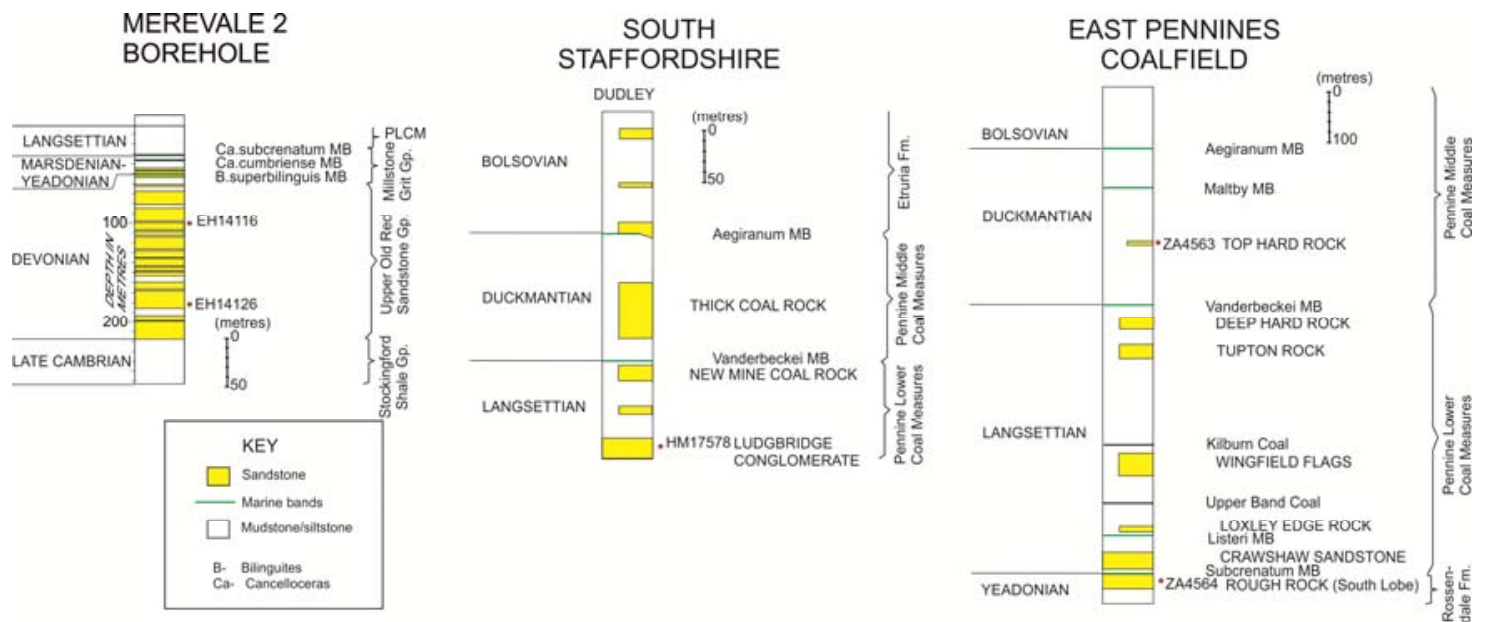

Figure 4. Stratigraphic distribution of samples of Devonian and Yeadonian-Duckmantian ages discussed in this paper. Merevale 2 Borehole log adapted from Taylor and Rushton (1971). 

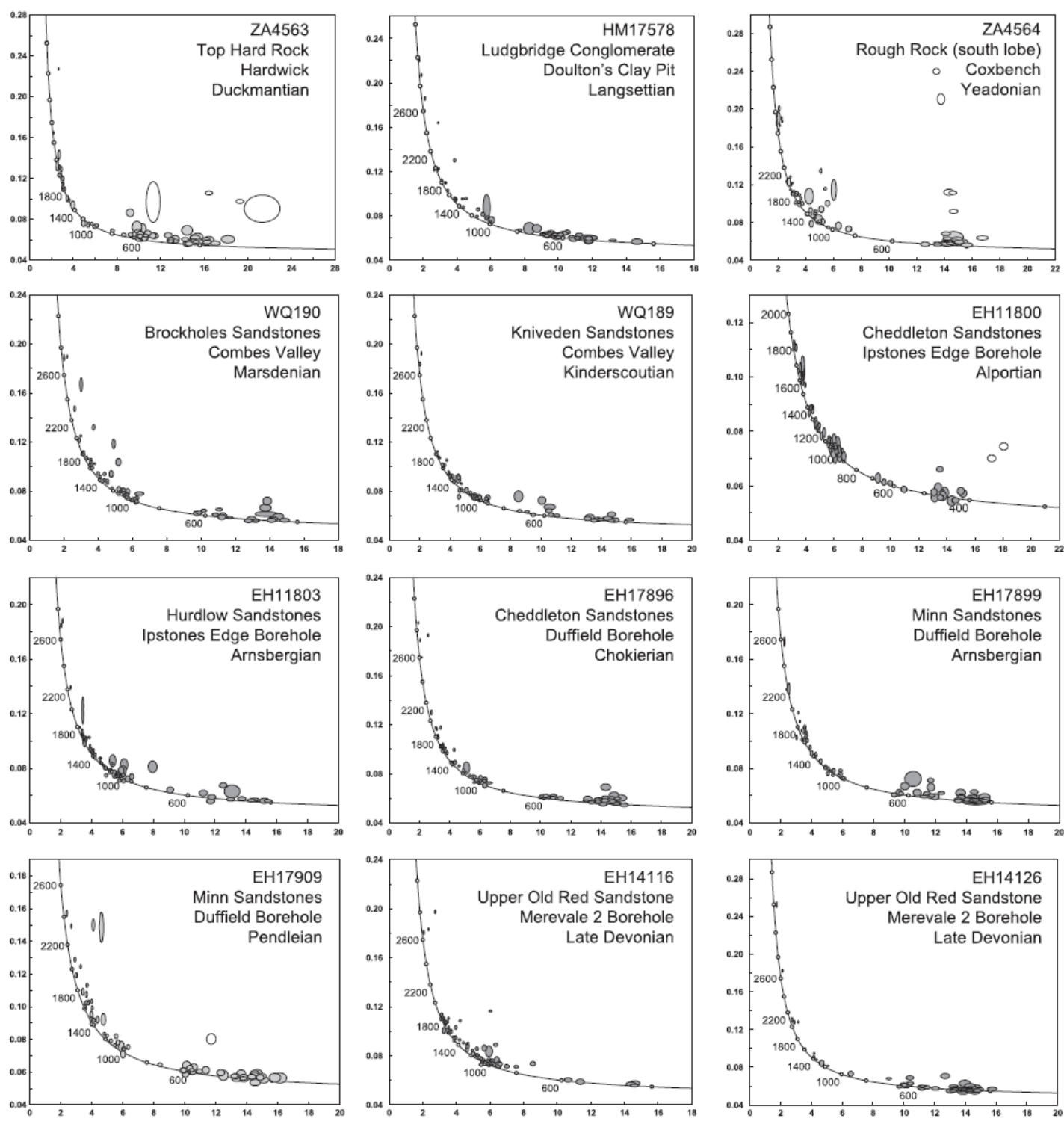

Figure 5. U-Pb isotopic compositions of detrital zircons plotted on Tera-Wasserburg (1972) concordia diagrams generated using ISOPLOT/EX (Ludwig, 2003). Error ellipses are $1 \sigma$. Open ellipses are analyses with high common $\mathrm{Pb}$, with consequent uncertainties concerning crystallisation age. 

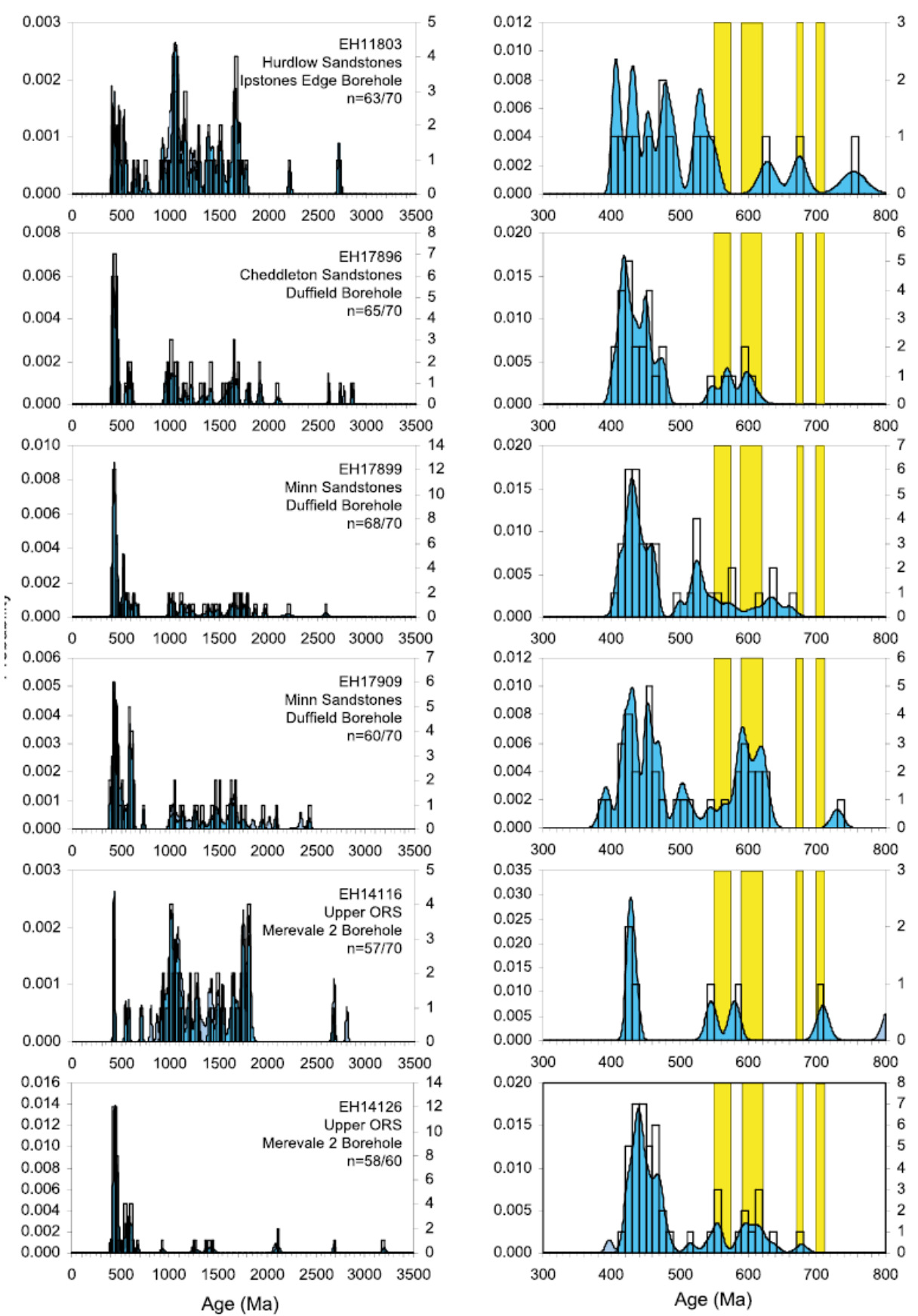

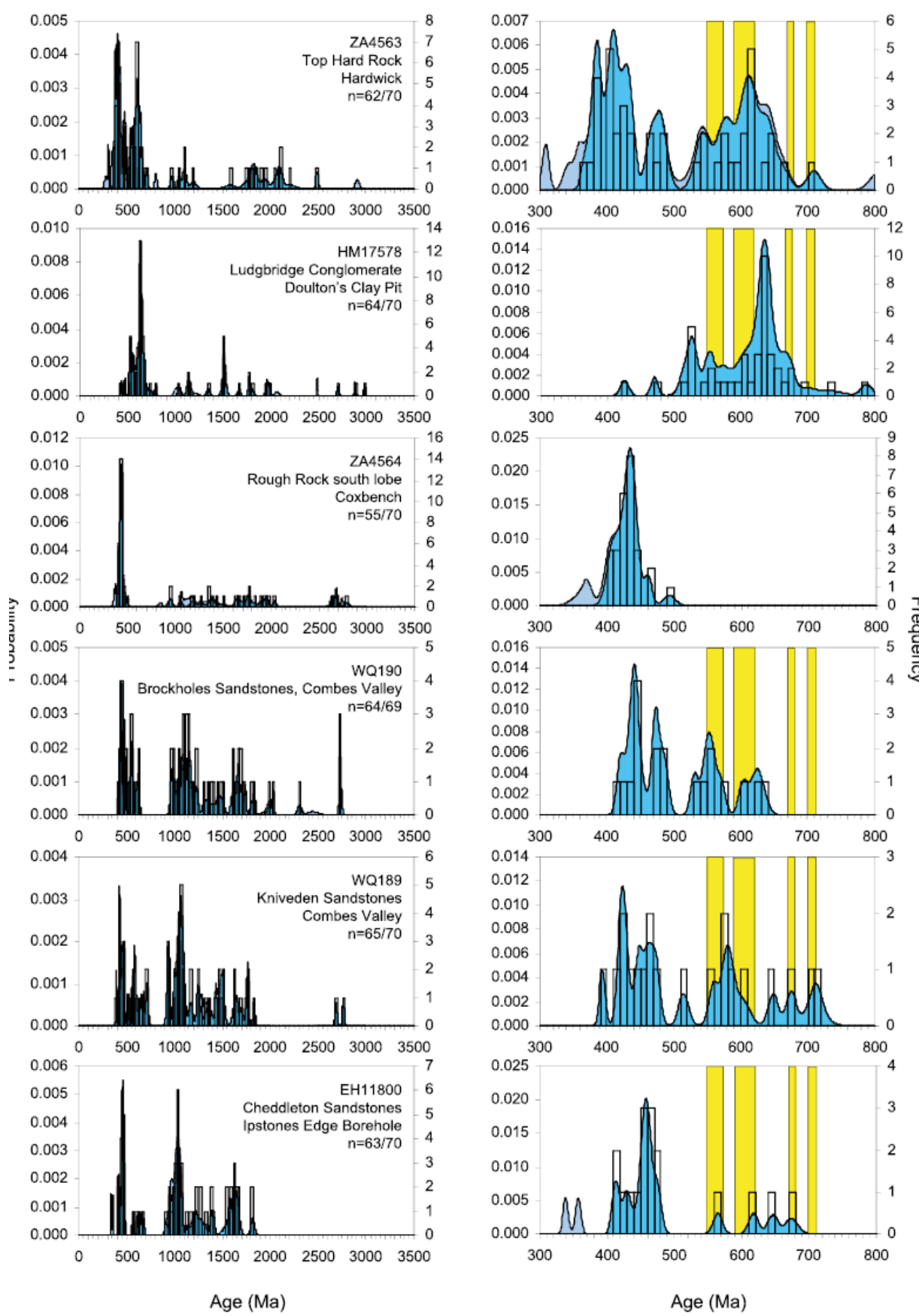

Figure $6 \mathrm{a}$ and $\mathrm{b}$. Probability-density diagrams showing detrital zircon ages for samples discussed in this paper. Diagrams on the left show the full range of zircon ages; those on the right are an expansion of the 300-800 Ma age range. ' $n$ ' is the number of zircons with $<10 \%$ discordance (for grains older than $\sim 800 \mathrm{Ma}$ ) plus those younger than $\sim 800 \mathrm{Ma}$ that are considered reliable on the basis of their position on concordia (Fig. 5) and their common $\mathrm{Pb}$ content, in the total zircon population. Yellow bars mark the ages of known Neoproterozoic magmatism on the WBM, from Stephenson and Highton (2000) and Compston et al. (2002). Dark blue areas show zircons with reliable ages, pale blue are zircons with $>10 \%$ discordance. 

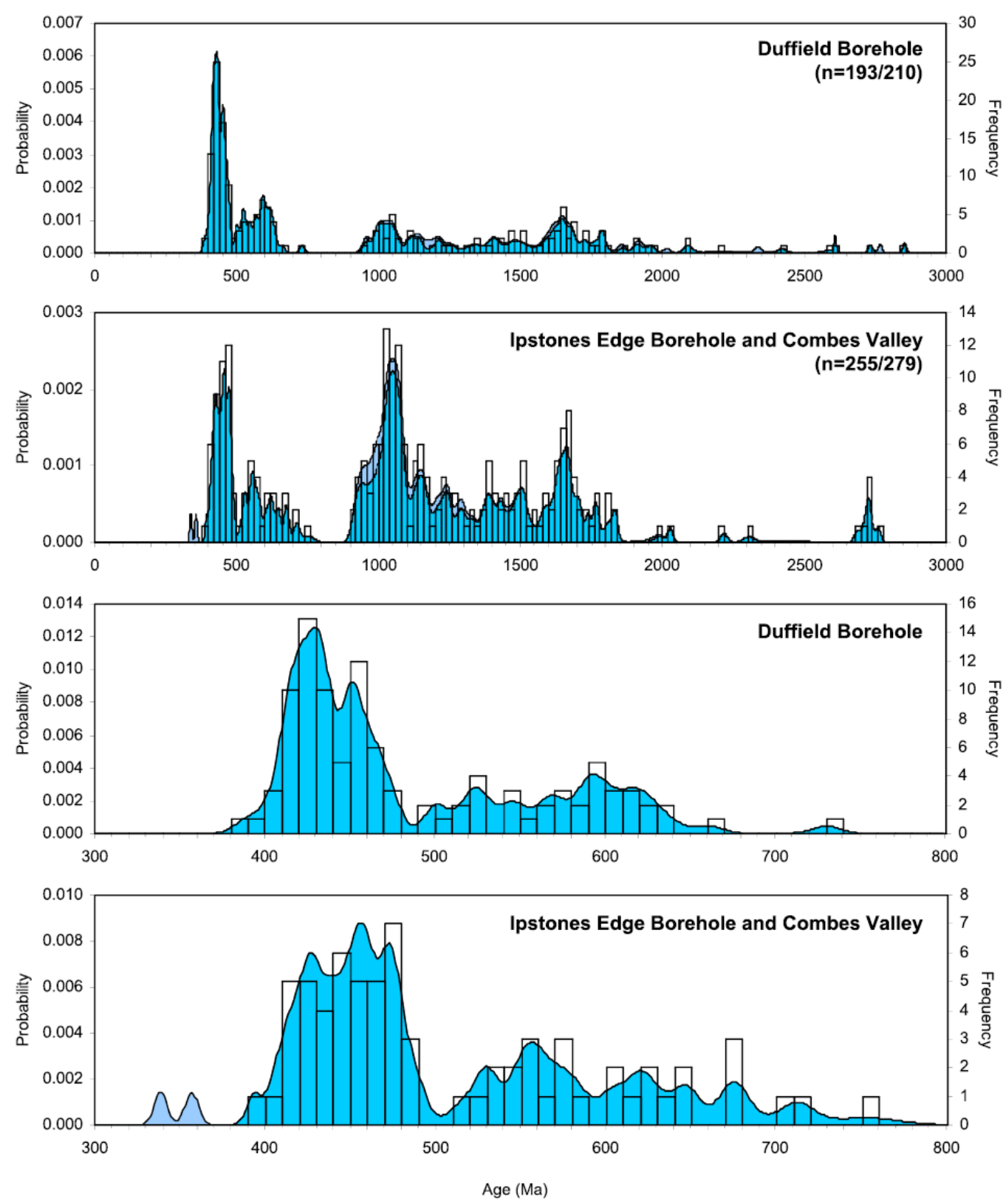

Figure 7. Probability-density diagrams comparing zircon ages from the Morridge Formation in the Duffield Borehole with those from the Ipstones Edge and Combes Valley area. Upper two diagrams show the full zircon age range; lower two show the 300-800 Ma range. 


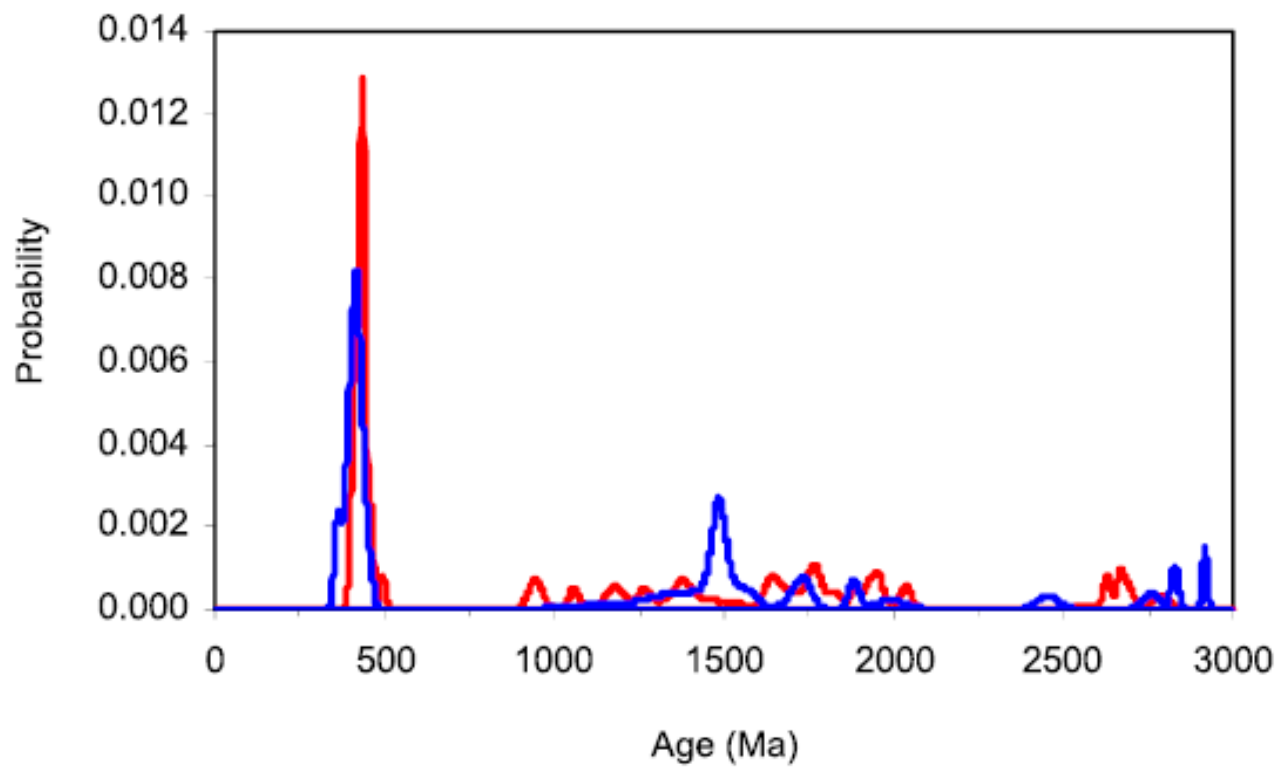

Figure 8. Relative probability diagram comparing zircon ages in the Rough Rock south lobe (red) with those from the main Rough Rock (blue). Plot uses only concordant and near-concordant zircons (as defined in the caption for fig. 6). The main Rough Rock data are from Hallsworth et al. (2000). 


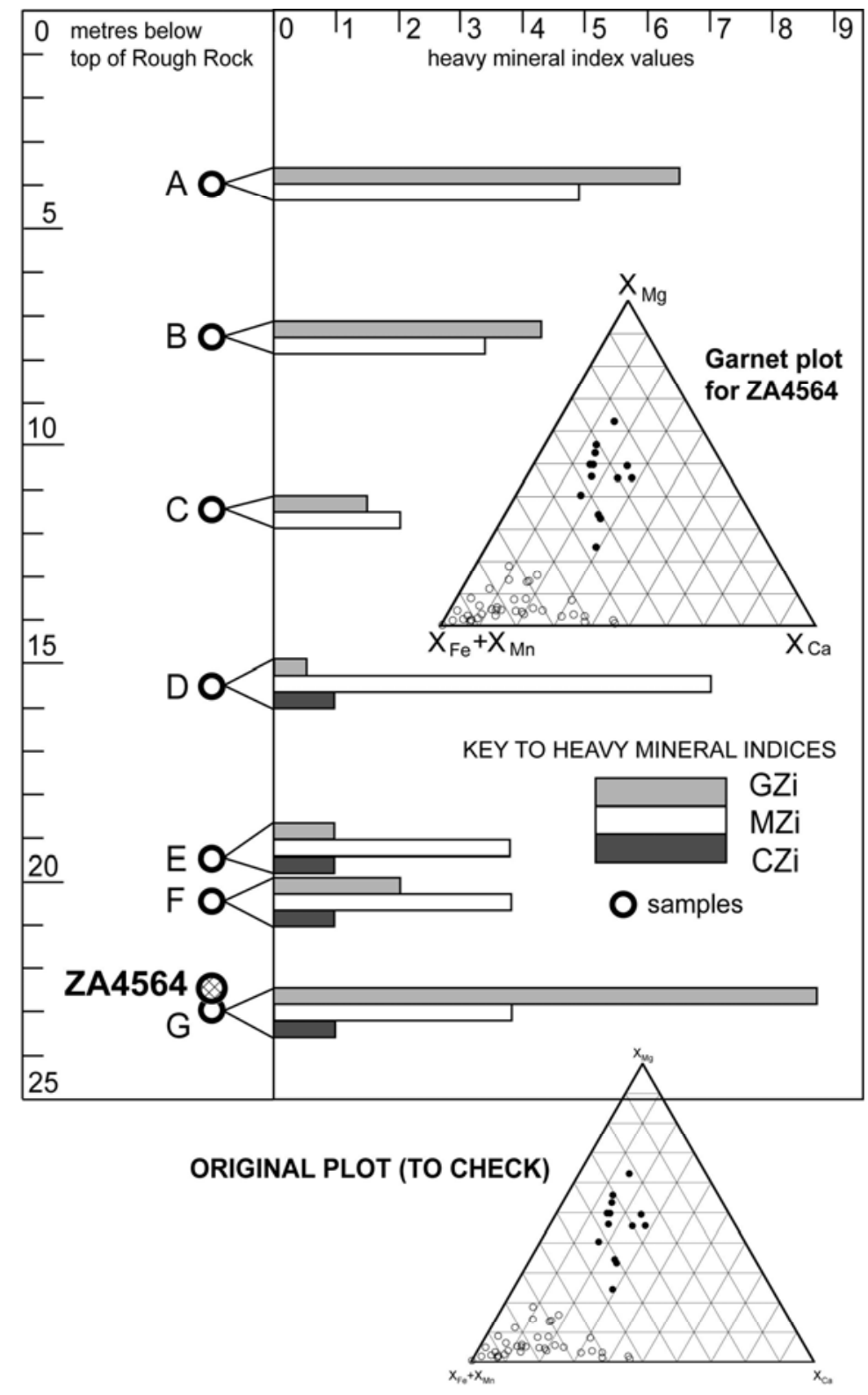

Figure 9. Details of a section in the south lobe of the Rough Rock at Coxbench (Fig. 2), based on Hallsworth and Chisholm (2008, fig. 13). Heavy mineral index measurements on samples A-G show variation that was attributed to mixing of 'northern' and 'southern' source sediments. GZi is garnet:zircon index, MZi is monazite:zircon index, CZi is chrome spinel:zircon index. Sample ZA4564 (analysed in the present study) contains zircons with a 'northern' age profile, but the garnet assemblage (inset) lacks the high-Mg, low-Ca types typical of northerly-derived Namurian sediment. Garnet ternary uses proportions of $\mathrm{Fe}$ and $\mathrm{Mn}\left(\mathrm{X}_{\mathrm{Fe}}+\mathrm{X}_{\mathrm{Mn}}\right), \mathrm{Mg}\left(\mathrm{X}_{\mathrm{Mg}}\right)$ and $\mathrm{Ca}\left(\mathrm{X}_{\mathrm{Ca}}\right)$ in the garnet molecule, with all Fe calculated as $\mathrm{Fe}^{2+}$. Garnets with $\mathrm{X}_{\mathrm{Mn}}<5 \%$ are shown as filled circles, those with $\mathrm{X}_{\mathrm{Mn}}>5 \%$ as open circles. 


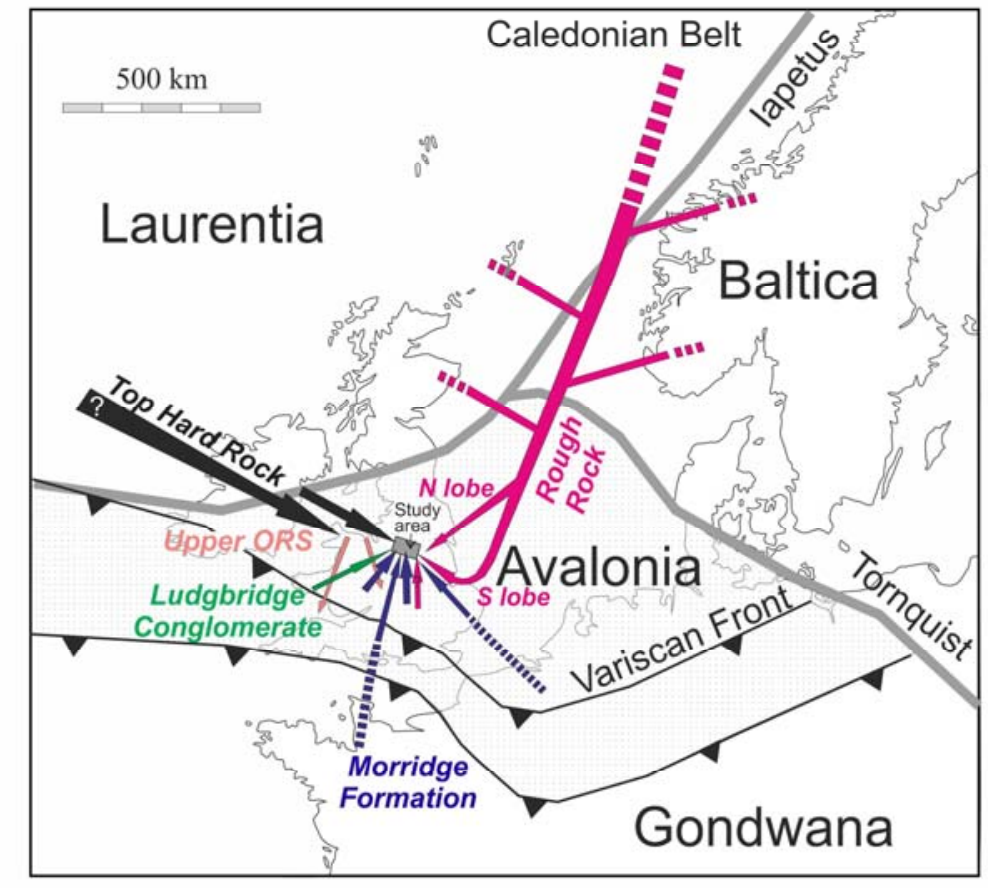

Figure 10. Interpreted sediment transport pathways for the Carboniferous sandstones fringing the northern margin of the Wales-Brabant Massif discussed in this study. Upper Old Red Sandstone transport routes are based on Leeder (1988), but zircon age data presented herein require involvement of a distal Caledonian source. This may be direct, or indirect by recycling of Lower ORS as proposed by Soper and Woodcock (2002). Boxed area is the study area as shown in Fig. 2. Rough Rock Main Lobe transport route is taken from Gilligan (1920), Cliff et al. (1991) and Hallsworth et al. (2000). 